\title{
On the effectiveness of exchange rate interventions in emerging markets
}

\author{
Christian Daude, Eduardo Levy Yeyati \\ and Arne Nagengast
}

CID Working Paper No. 288

September 2014

(C) Copyright 2014 Daude, Christian; Levy Yeyati, Eduardo; Nagengast, Arne; and the President and Fellows of Harvard College
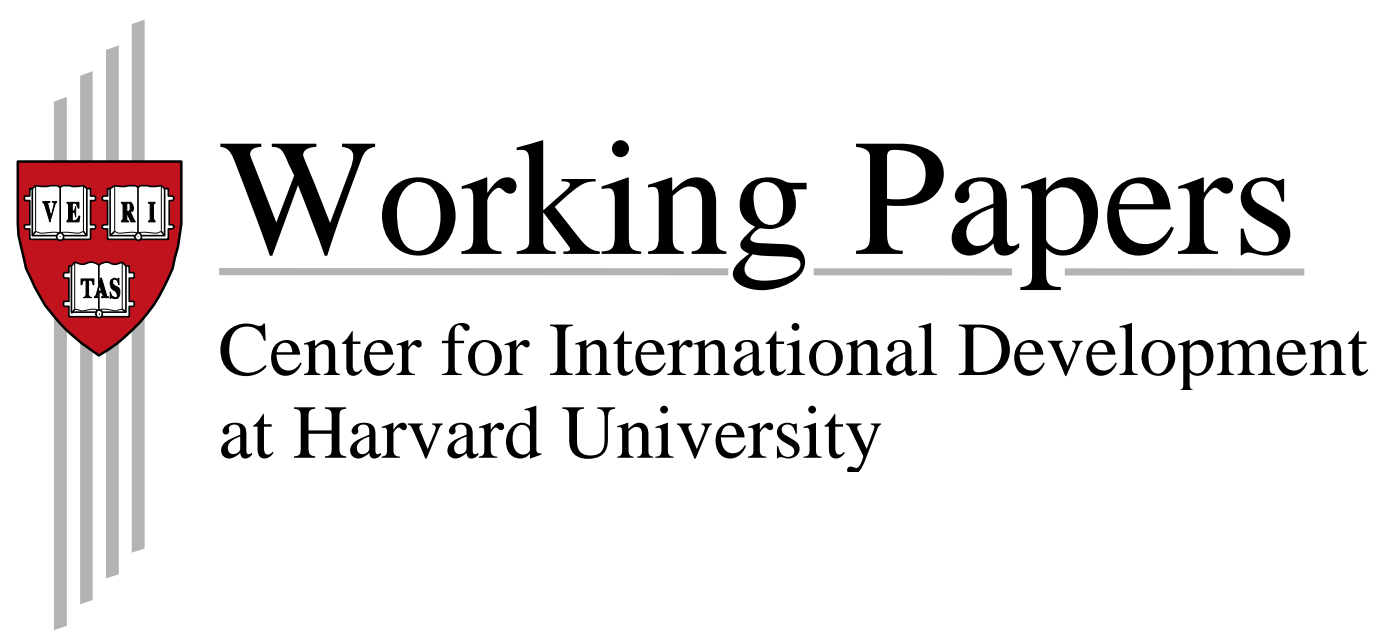


\title{
On the effectiveness of exchange rate interventions in emerging markets
}

\author{
Christian Daude \\ Organisation for Economic Co-operation and Development \\ Eduardo Levy Yeyati \\ Universidad Torcuato Di Tella \\ Arne Nagengast \\ Deutsche Bundesbank
}

\begin{abstract}
We analyze the effectiveness of exchange rate interventions for a panel of 18 emerging market economies during the period 2003-2011. Using an error-correction model approach we find that on average intervention is effective in moving the real exchange rate in the desired direction, controlling for deviations from the equilibrium and short-term changes in fundamentals and global financial variables. Our results are robust to different samples and estimation methods. We find little evidence of asymmetries in the effect of sales and purchases, but some evidence of more effective interventions for large deviations from the equilibrium. We also explore differences across countries according to the possible transmission channels and nature of some global shocks.
\end{abstract}

JEL-classification: F31, F37

Keywords: exchange rate; $\mathrm{FX}$ intervention; equilibrium exchange rate 


\section{INTRODUCTION}

Few macroeconomic policy topics have been as hotly debated as the exchange rate policy of emerging economies. From the varieties of pegs of the 70s and 80s to the bipolar (float or fix) view of the 90s, from the floating with inflation targeting paradigm of the early 2000 s to the "leaning against the wind" intervention of recent years, exchange rate policy have tended to follow perceived lessons from crisis and respond to the ongoing macroeconomic juncture; hence, its apparent mercurial nature. ${ }^{1}$ Nowhere has this debate been so predominant as in Latin America, a laboratory for all sorts of creative solutions to the classic exchange rate dilemma, namely, how to reconcile flexibility, on the one hand, and external competitiveness and financial and macroeconomic stability, on the other. In this paper, we document that leaning-against-the-wind exchange rate intervention in emerging economies has a significant impact on the real exchange rate.

There are in principle two main reasons behind exchange rate intervention: the perception that the exchange rate is moving away from a given target and the perception that it is moving away from its equilibrium (or too fast towards a potentially new equilibrium). The difference between the two cases should be obvious. The first one implies a degree of explicit (or implicit) rigidity in the exchange rate that the intervention is intended to preserve. In the second case, by contrast, intervention is "corrective": it attempts to smooth out deviations from equilibrium or volatility deemed to be potentially damaging (possibly in both direction although not necessarily in a symmetric way), relative to an exchange rate "comfort zone" that reflects the behavior of a set of moving fundamentals.

In other words, whereas in the first case the exchange rate is a predetermined target (to work as a nominal anchor or as a tool to enhance international competitiveness and import protection), in the second it is a flexible relative price that, to the extent that it is prone to cyclical deviations and misalignments (as well as sudden changes and overshooting), needs to be contained by active policy. Given that many emerging markets (and nearly all economies in the broader sample used in the empirical exploration of this paper) run a more or less flexible exchange rate regime and

\footnotetext{
${ }^{1}$ See Sarno and Taylor (2001) for an early survey with a focus on advanced countries, and Levy Yeyati and Sturzenegger (2010) for a recent one with a focus on developing economies.
} 
could be grouped under the second case, in what follows we will focus on countercyclical intervention of the second kind.

After so many ups and downs in the global financial cycle (the reflection of the not-alwayscorrelated swings in global liquidity, financial risk and risk appetite), the role of exchange rate policy as a standard countercyclical tool has become increasingly apparent. While exchange rate flexibility helps mitigate real (terms of trade) shocks in the textbook Mundell-Flemming framework, the questions remains whether full flexibility should be allowed vis-à-vis more transient financial shocks in a financially integrated emerging world, so that exchange rates appreciate during the rallies of risky assets during the risk-on phase of the global financial cycle and depreciate with the sharp selloffs that typically come at the time of the risk-off reversal. The "leaning against the wind" nature of most exchange rate policy in the emerging world (and in some advanced economies) seems to indicate that, at least from a policy-making perspective, this textbook type of flexibility is often seen as more harmful that beneficial.

However, the debate at the economic mainstream has typically downplayed the exchange ratesmoothing nature of intervention, attributing it to the precautionary or prudential motives of reserve accumulation/decumulation, and grouping the direct sales and purchases of foreign exchange with other related measures such as taxes or restrictions on capital mobility or differential reserve requirements. ${ }^{2}$ However, there is plenty of evidence, both anecdotal and hard, indicating that intervention is primarily geared to limiting what policy makers tend to see as unwarranted (and possibly harmful) deviations from equilibrium levels: intervention correlates negatively with exchange rate pressure and is often complemented with capital restrictions and taxes that could only make any precautionary reserve build-up more costly. ${ }^{3}$ This contrasts with the longer debate in the academic literature, which has concentrated on intervention strategies to postpone or limit a devaluation (as in the "fear of floating" view) or, on the other extreme, to preserve depreciated real exchange rates to foster growth and prevent "Dutch disease" effects (which we could label the "development" view of exchange rate policies). ${ }^{4}$

\footnotetext{
${ }^{2}$ For a discussion of the precautionary and prudential motives see Aizenman and Lee (2007) or Obstfeld et al. (2010). The taxes and capital mobility explanations of the sales and purchases of foreign currency are discussed in a recent IMF External Sector Report (see http://www.imf.org/external/np/pp/eng/2013/062013.pdf,.pp 17 to 20).

${ }^{3}$ See, i.a., Levy Yeyati (2010) and Adler and Tovar (2011).

${ }^{4}$ The postponement of depreciations is discussed in Haussman et al. (2000) and in Calvo and Reinhart (2002). The growth motive of keeping a depreciated currency is discussed in Rodrik (2008), Haussman et al. (2005) and Johnson
} 
However, a case can be made (as we attempt to do here) that most, if not all, exchange rate intervention should be regarded, more generally, as a countercyclical macroeconomic tool aimed at smoothing out short-run currency swings and to limit volatility. Indeed, fears of deviations in either direction could be reconciled with a broader fear of exchange rate instability due to transient or cyclical (and, at any rate, reversible) factors - a fear that, in turn, relates to the potential impact of exchange rate misalignments on economic growth and financial stability. Thus, for example, the reluctance of commodity exporters to let the real exchange rate appreciate to reflect the commodity price boom in the early and mid-2000s would be driven not so much to keeping the currency undervalued in a disguised beggar-thy-neighbour strategy as suggested by the "development view" as to minimizing the size (and the economic costs) of an exchange rate correction should the commodity cycle revert -as it actually did in 2008-2009 during the global recession. On the other extreme, "fear of floating" interventions to slow down short-lived depreciations may be seen as geared towards mitigating avoidable inflation pass-through or, in financially dollarized economies, balance sheet effects on currency-imbalanced firms and banks. Naturally, the exchange rate dynamics and the nature of the concerns differ according to direction of the correction: it follows that both the reaction function of the monetary authority and its impact on the exchange rate should, in principle, be asymmetric.

Whatever view behind central bank interventions we are willing to endorse, perhaps the most critical, and possibly the most controversial aspect of the debate is whether interventions are effective by exerting a significant and lasting influence on the exchange rate behavior, both on its level and on its volatility.

A series of surveys by the BIS (2005, 2013) and the World Bank (de la Torre et al, 2013) exploring the motives and effectiveness of intervention from the perspective of the central banks of emerging economies, support the view that Central banks intervene actively, especially in the spot market, to prevent excessive swings of the exchange rate (the "leaning against the wind" motive) and that interventions are seen as an effective tool to achieve this objective (Table 1).

et al (2010), or Glüzmann et al. (2012). For "Dutch disease" type concerns and evidence see Rajan and Subramanian (2011), or Cárdenas et al. (2011) for the case of LAC. 
[INSERT Table 1 here]

However, because of the two-way causality between intervention and exchange rate variations: central banks purchase (sell) dollars to partially offset appreciations (depreciations), the literature has not been successful at documenting a significant and systematic link between interventions and their desired effect on the exchange rate, which typically prove to be not significant and, sometimes, show up with the "wrong" sign.

Moreover, not all interventions are exchange rate driven: as a large body of research on developing economies has shown that, at least in some cases and to some extent, intervention may be due to reserve restocking after a currency crisis (Aizenmann and Lee, 2007), or to reserve precautionary stock building (and un-building) so as to ensure a given reserve coverage of monetary aggregates to dissuade potential speculative attacks on the national currency. In particular, Obstfeld et al. (2010) argue that the relevant intervention objective is not to keep reserves constant relative to GDP, exports or dollarized obligations but rather to keep it stable relative to the broad monetary aggregate, the one that typically runs against reserves in a currency attack. It follows that, for our measure of central bank intervention to capture exchange rate rather than precautionary motives, it is essential to filter out precautionary reserve accumulation.

In this paper we test the effect of interventions on the real exchange rate using an intervention measure that filters out possible precautionary causes, within an error correction model that takes into account jointly RER dynamics, controlling for the fundamental determinants governing its long-term (equilibrium) trend as well as and short-term non-fundamental financial drivers. We also test for asymmetry (differential responses to dollar sales and dollar purchases) and nonlinearities relative to the size of the shock (to explore, in particular, whether episodes of heavy dollar sales during crises are effective). Unlike in the recent related literature, we find that intervention is significantly associated with the real exchange rate in the expected way, whereby dollar purchases lead to a more appreciated currency whereas dollar sales tends to dampen depreciation pressures. Interestingly, despite de skewness of the distribution of exchange rate 
changes (where depreciations are sharper but less frequent than appreciation), we find little evidence of asymmetry. Our results survive several robustness checks.

The paper is organized as follows: section 2 describes data definitions and sources, section 3 reports the results and the robustness tests, and section 4 concludes.

\section{Data, definitions and methodology}

This section presents the main data and methodology used in our econometric tests of the effectiveness of central bank intervention on exchange rate behaviour. We adopt a two-stage, error correction model: we estimate first the equilibrium real exchange rate as a long run relationship between the latter and a set of standard macroeconomic fundamentals to obtain a measure of exchange rate misalignment, and next we run a short-run model of real exchange rate changes on the exchange rate misalignment and the change in the fundamentals, augmented by additional non fundamental financial variables that may introduce short-term deviations, and our measure of intervention. In what follows we describe each stage in more detail.

\section{a. Exchange rate deviations: Estimating the equilibrium RER}

In order to know whether the exchange rate has gone too far away from equilibrium (to identify a deviation) we need to define an equilibrium (or "normal") level. This is, of course, a nontrivial task given that some of the natural drivers of the real effective exchange rate (RER), including many of the fundamental ones, tend to display volatile cyclical patterns, making any simple estimate of the equilibrium zone a moving target.

A recent paper by the IMF (2013) illustrates both the complexity and the drawbacks of any exercise geared to pin down equilibrium RER (ERER). The paper lists three types of arguments behind the RER: i) traditional fundamentals: productivity, population growth, commodity terms of trade, trade openness, share of administered prices to CPI; ii) short-term (financial and cyclical) 
factors: VIX, interest rate differentials (which the IMF groups under the "policy" group), financial home bias, expected GDP growth; iii) policy variables: capital controls, FX intervention, health expenditure to GDP, private credit to GDP (a proxy for macro prudential policies). ${ }^{5}$

The estimation of a panel of RER against this set of variables open the question about what level of the policy variables should be considered in order to evaluate the equilibrium level of the RER. The IMF addresses this question by specifying a policy benchmark for each of these variables, according to what "the country desks suggest would be desirable for the future"-which adds a degree of subjectivity and entails some normative judgment. Similarly, there is the question about the extent to which cyclical and short-term financial variables should be reflected in the estimated equilibrium RER, rather than as explanatory factors behind its deviation from its fundamental level.

Note, however, that a more traditional approach (as the one taken, e.g., in IMF (2006) or Bello et al. (2010) that restricts attention to traditional fundamentals and leave non fundamental and policy aspects aside) faces a problem that is the flipside of the previous one: if policies (or, to a lesser extent, financial variables) drive the RER persistently away from the equilibrium, ignoring those variables in the estimation may bias the results. For example, we may see equilibrium exchange rates more undervalued than they actually are if they have been systematically influenced by central bank foreign exchange purchases uncontrolled for in the model. ${ }^{6}$

At any rate, given that there seems to be no uncontroversial way to approach the problem, here we opt for the one that calls for the smaller set of normative assumptions regarding policy. Thus, we estimate the long-run RER as a function of standard fundamentals: productivity (prod), commodity terms of trade (ctot), net foreign assets (NFA), trade openness (open) and government consumption to GDP (gov), using a dynamic ordinary least squares (DOLS) estimation with quarterly data (interpolated using cubic spline when only annual frequencies are available). ${ }^{7}$ In

\footnotetext{
${ }^{5}$ The net foreign asset position (a fundamental), the output gap (cyclical) and the fiscal balance (a policy variable) all fail to deliver significant results.

${ }^{6}$ The bias should be smaller, however, if the omitted variables are not correlated with the rest of the fundamentals (or tend to cancel each other over time).

${ }^{7}$ The real effective exchange rate (RER) comes from the BIS; net foreign assets (NFA) over GDP from the update of Lane and Milessi Ferretti (2007)'s wealth of nations dataset; commodity terms of trade (CTOT) from "The history of booms and busts" dataset; productivity (PROD), proxied by ratio of GDP per capita to the US in PPP terms, from the Penn World tables; and government consumption over GDP (GC) and openness (OPEN), computed as exports plus
} 
particular, we include the contemporaneous levels of the fundamentals - our main coefficients of interest - as well as a one-quarter lag and lead terms, in addition to the contemporaneous term, of the first difference of all fundamentals. ${ }^{8}$ We use a balanced sample of emerging and advanced economies. In order to address the idiosyncratic nature of the fundamental determinants of ERER, in addition to pooling all countries we also estimated the model by region as well as by grouping all emerging markets. ${ }^{9}$

The results, reported in Table 2, are mostly significant and consistent with the priors. The equilibrium level of the real exchange rate increases (appreciates) with productivity, terms of trade, net financial assets (NFA), and government consumption; and decreases (depreciates) with trade openness.

[Insert Table 2 here]

In turn, using the coefficients from the model reported in the table, we construct two "versions" of the ERER: one associated with the values of fundamentals at any given point in time (the fitted values of the regression), which we label as "ERER based on current fundamentals", and another one based on the medium-term values of the same variables, which we estimate as the HP-filtered trend and label "ERER based on trend fundamentals".

\section{[Insert Figures 1 and 2 here]}

A few aspects stand out from our estimates of equilibrium real exchange rates. First, real exchange rates in EM display a larger volatility than in advanced economies (particularly, in LAC). For example, the deviation with respect to the equilibrium exchange at current fundamentals is on average more than twice more volatile in EM than in advanced economies.

imports over GDP, are from the IMF's IFS. GC, PROD and OPEN are computed relative to the country's trade partners. We prefer to estimate the model using the realized values of the variables (rather than their trends as in Bello et al. (2010) to capture the elasticities of the RER more precisely.

${ }^{8}$ All variables are taken in logs, with the exception of net foreign assets, which are measured as a share of GDP.

${ }^{9}$ Note that this simplified approach implicitly assumes that the relationship between RER and fundamentals are similar across economies and that economies in the simple are, on average, in line with fundamentals (in other words, there is no systematic deviation from the equilibrium in the simple as a whole). Hence, the trade-off between a broader simple (which forces the coefficients to be the same across regions and levels of development) and a narrower simple (which may asume persistent ERER misalignments as normal). 
Second, despite the presence of heavy intervention, the boom and bust cycle around the 2008 financial collapse was associated with important deviations from the predicted equilibrium values, based either on realized or trend fundamentals - a finding that a priori justifies the leaning against the wind policy displayed by many countries in the region. Third, fundamental values of the RER may differ significantly depending on whether they are estimated based on current or trend (that is, medium run) fundamentals, which may motivate intervention to offset, for example, capital flows or a commodity bonanza that are perceived to be temporary. This last fact holds especially for EM compared to advanced economies (Figure 2).

\section{b. Measuring intervention}

A normative assessment of the optimal degree of intervention exceeds the scope of this paper. But a positive question about its effectiveness is a good starting point: Can intervention depress the value of the currency? There is surprisingly little consensus about the capacity of intervention to fend off appreciation pressures; on the other hand, policymakers seem to prefer intervention to benign neglect, despite the skepticism often voiced in academic and policy circles.

Quantifying this effect is not simple, because it entails not only a good account of other factors that may be pressing on both the exchange rate and the level of reserves but also an accurate measure of intervention itself. Intervention data is scarce and often substituted for reserve changes, which may occur for reasons arguably unrelated to central bank intervention, including the accrual of interest, the liquidation of foreign currency receipts by public companies, or the rebuilding or reduction of the reserve buffer driven by prudential considerations. ${ }^{10}$ And many alternative or complementary vehicles of intervention described above (changes in the currency composition of government debt or in the local interest rate, or intervention in futures markets), while typically marginal compared with spot intervention as noted above, are difficult to trace systematically and often left aside in empirical tests.

\footnotetext{
${ }^{10}$ Adler and Tovar (2011) highlight this point, but document that differences between changes in reserves and actual intervention at lower-than-weekly frequencies tend to be minor at uncorrelated with exchange rate changes. In turn, Obstfeld et al. (2010) argue that prudential reserves tend to move together (ultimately, to cover) broad money aggregates such as M2 to avoid double bank and currency runs. Note that an appreciation can cause the central bank to build reserves if the latter are held for precautionary motives, as a stronger currency "deteriorates" the reserve-tomoney coverage ratio because of valuation changes. The change in the reserve-to-M2 ratio used as a proxy for intervention below mitigates this potential bias.
} 
Moreover, interventions usually take place when the exchange rate is moving or expected to move in the opposite direction to the expected effect of the intervention. This 'endogeneity' problem usually results in intervention showing with the wrong sign in exchange rate regression equations, with purchases (sales) of dollars associated with an appreciation (depreciation) of the local currency, and no simple way to estimate the counterfactual exchange rate under no intervention.

To filter out the prudential motive for intervention and minimize the endogeneity bias, Levy Yeyati et al. (2013) proposed to use, as a "strict" proxy for intervention, the change in the reserves-to-M2 ratio (where reserves are computed as the central bank's net foreign asset position excluding gold).

In turn, a natural approach would be to model the variation of the RER, controlled for deviations from its long-run fundamental value and for short-run drivers as we did in Table 1, augmented with a proxy of central bank intervention as defined above. ${ }^{11}$ We use the ERER based on trend fundamentals estimated based on Table 1 to compute the deviation of the RER from its equilibrium level. In turn, we use this deviation, along with changes in fundamentals, in an error correction equation augmented with the intervention variable. Finally, to correct for the endogeneity bias (the fact that intervention may respond to changes in the exchange rate as much as the other way around), we instrument intervention with the change in the M2-to-GDP ratio.

More formally, our econometric specification is given by:

$$
\begin{aligned}
& \Delta \ln \left(R E R_{i t}\right)=\rho \Delta \ln \left(R E R_{i t-1}\right)+\alpha\left(R E R_{i t-1}-E R E R_{i t-1}\right)+\Delta x_{i t}^{\prime} \beta+\Delta z_{i t}^{\prime} \delta+\gamma I N T_{i t}+\mu_{i}+ \\
& \varepsilon_{i t}
\end{aligned}
$$

where the first two terms on the right-hand side are the lagged dependent variable and the error correction terms, respectively. The vector of the first differences of the fundamental drivers of the ERER is given by

\footnotetext{
${ }^{11}$ As noted, the specification is leaving aside other policy measures that may affect the exchange rate: while some of them (changes in reserve requirements, capital controls) have a low frequency that is unlikely to alter significantly the results of the test, the omission of intervention in derivative markets or through interest rates may bias somewhat the results.
} 
$\Delta x_{i t}^{\prime}=\left[\begin{array}{lllll}\Delta \ln \left(\operatorname{ctot}_{i t}\right) & \Delta o p e n_{i t} & \Delta n f a_{i t} & \Delta \ln \left(\operatorname{prod}_{i t}\right) & \Delta g o v_{i t}\end{array}\right]$

to which we add a set of financial drivers that might drive exchange rate movements in the shortterm:

$\Delta z_{i t}^{\prime}=\left[\Delta \ln \left(V I X_{t}\right) \quad \operatorname{carr} y_{i t}\right]$

where the VIX, an index of implied volatility of options on the S\&P500, proxies for global risk appetite, and the interest rate differential with respect to the USD interest rate (carry) controls for short-term speculative demand for the currency.

Our variable of interest is the intervention variable is $I N T_{t}=\left(\frac{R}{M_{2}}\right)_{t}-\left(\frac{R}{M_{2}}\right)_{t-1}$

Finally, the error term is assumed to comprise a country-specific fixed effect $\left(\mu_{i}\right)$ and a white noise random term such that $E \varepsilon \varepsilon^{\prime}=\sigma^{2} I$.

\section{Empirical results}

This section presents the main results from an error-correction panel model of the dynamics of the real exchange rate using the sample described in the previous section. Furthermore, we analyse the robustness of our results to different estimation methods, alternative samples, and regional differences in the effect of FX intervention. In addition, we explore a series of non-linearities and interactions with global risk and USD shocks. 


\section{a. Baseline results}

Table 3 reports the results from the estimation of equation (1). ${ }^{12}$ Focusing on the first four columns, a series of interesting results emerge. First, in terms of our main variable of interest, FX interventions - specifically an increase (decrease) in the ratio of reserves to M2 - lead to a depreciation (appreciation) of the real exchange rate, according to column (1) in Table 3. In terms of magnitude, the coefficient shows that a 1 percentage point increase in INT is associated with a $0.18 \%$ depreciation of the real exchange rate. Second, the error correction term is always negative, as expected, and significant at $1 \%$. Therefore, when the real exchange rate equilibrium appreciates relative to its equilibrium value, between $2.5 \%$ and $3.2 \%$ of the misalignment -depending on the specification- is reverted within the following month. This magnitude is in line with the literature, as the implied half-life in this case would be between 23 and 27 months, close to the 2.5 years often found in earlier studies. ${ }^{13}$ Finally, the results also show a negative and significant impact of changes in global risk aversion - proxied by changes in the VIX - on the real exchange rate in emerging markets (EMs). This is in line with the anecdotal evidence that global risk-off events are typically associated with emerging currency sell offs. ${ }^{14}$

Clearly, our intervention variable could be endogenous, because of valuation effects or because the central bank might intervene by buying reserves during appreciation episodes and selling during depreciations. It is important to point out that this would be an attenuation bias, reducing the size of the coefficient towards zero compared to the true coefficient. Therefore, the estimate in column 1 would be a lower bound estimate of the true effect. In order to address this potential endogeneity, we estimate a country-specific reaction function that includes all additional controls from equation (1) and the first difference in the ratio of M2 to GDP as an instrument. The rationale for the use of this instrument is to capture changes in the reserve to M2 ratio associated with financial stability and precautionary reasons, as argued by Obstfeld et al (2010). In column (2) we present the results using the instrumented intervention variable. Consistent with the

\footnotetext{
12 The estimates use the ERER based on the whole sample (emerging and developed economies) from column 6 in Table 1. Results are robust to this choice. They are omitted here due to space considerations, but available upon request

${ }^{13}$ See e.g. Kubota (2013) and references therein.

${ }^{14}$ Alternatively, using the yield of low-grade US corporate bonds or a combination of the latter and the VIX renders the same result.
} 
attenuation bias of the reverse causality described above, once instrumented the point estimate of the FX intervention effect increases almost three times compared to column (1).

[Insert Table 3 here]

Next, in columns (3) and (4) we explore whether there are significant differences between the effects of buying or selling reserves. Results are mixed; while for the original specification there seems to be no significant asymmetry, in the instrumented version the effect of foreign currency sales is significantly smaller (almost half the size) than that of purchases.

Our baseline results (columns 1 to 4 ) are estimated using the least-squared dummy variable (LSDV) estimate, which generally are biased due to the endogeneity of the lagged dependent variable (Nerlove, 1971; Nickell, 1981). Therefore, in columns (5) to (8) we replicate the estimation using a bias-corrected LSDV estimate based on Kiviet $(1995,1999)$ and extended to unbalanced panels by Bruno (2005a; 2005b). ${ }^{15}$ Despite somewhat overall less significant coefficients (e.g. for the error correction term and several of the controls), the main results regarding central bank intervention are remarkably stable. The economic significance of the effects of interventions barely changes from the original or the instrumented version. The same is true, to a lesser extent, for the difference between sales and purchases, although now there is no significant difference between sales and purchases in the instrumented version.

\section{b. Robustness and extensions}

The results discussed in the previous section bring to mine a number a basic robustness checks, covering issues of causality, initial conditions, and sample and country characteristics. This section summarizes the main findings of the many tests we run to examine the robustness of our results.

\footnotetext{
${ }^{15}$ The literature shows that the LSDVC estimator performs well in small samples. For example, as shown by Judson and Owen (1999), using Monte Carlo simulations, for panels of all sizes the bias corrected estimator consistently has the lowest root mean squared error in comparison to OLS, Anderson-Hsiao and GMM estimators. In this paper, we use the Bruno (2005b) implementation of the xtlsdvc routine in STATA, which is the software used in all econometric estimations in this paper.
} 
Is the intervention-exchange rate link just reflecting a valuation effect on the reserve-to-M2 ratio? Because there are several episodes in our sample in which INT increases (decreases) due to a decline (increase) in the denominator (M2) rather than to an increase in reserves, it could be argued that the negative association between the intervention and the RER is at least in part driven by valuation effects due to sudden exchange rate changes unrelated to intervention. For example, a currency selloff due to a peak of global risk aversion may lead to an increase in the reserve to M2 ratio regardless of (and generally before any) central bank intervention. To test whether our findings are robust to the exclusion of these episodes, we use a "restricted sample" that excludes observations for which the monthly change in reserves had the opposite sign as the change in reserves as a ratio of M2 (cases for which changes in the intervention variable can be attributed to changes in the exchange rate). Reassuringly, the results presented in columns (1) to (4) of Table 4 are comparable, albeit somewhat smaller, to those in Table 3.

Is intervention in emerging markets equally effective across emerging market groups? Differences across regions could arise, for example, from structural differences in their financial markets that might affect the effectiveness of intervention (as discussed in more detail below). In columns (5) and (6) of Table 4, we report estimates with region-specific interactions for LatAm, EMEA and Emerging Asia (the omitted interaction). Again, the findings seem to be remarkably stable: the results show no significant differences between Latin American, Emerging European and Emerging Asian economies. ${ }^{16}$

Is the effectiveness of intervention related to the initial misalignment? One could argue that wide deviations from the ERER create expectations of a reversal to equilibrium, amplifying the effect of any intervention by the central bank to that end. By contrast, intervention when the currency is near its equilibrium value is more likely to be offset by the market, anticipating a reversal to normal values. We test this hypothesis by focusing on the size of the gap with respect to the equilibrium exchange rate, interacting the intervention variable with a "large deviation" dummy (where "large deviation" is defined as one exceeding 10\%, the upper quartile of the absolute size deviations in our sample). Columns (7) and (8) report the results, supporting the previous hypothesis: the interaction has the expected negative sign, indicating that interventions are more

\footnotetext{
${ }^{16}$ Similar results are obtained when estimating separate regressions for each region that all for differences in all coefficients, not included for space considerations but available upon request.
} 
effective the larger the deviation, and is statistically significant for the "restricted sample". 17 Finally, we test whether the interaction displays asymmetric effects according to whether the central bank is buying or selling reserves. Again, we find that, while both for the full and the restricted sample intervention is more effective in the face of large deviations, the pattern seems to be more stronger when intervention takes the form of reserve purchases to curb appreciations.

[Insert Table 4 here]

Is the effectiveness of intervention conditioned by the characteristics of local financial markets? The economic literature has identified two main channels through which sterilized interventions can exert this influence: the portfolio and the signaling channel (Sarno and Taylor, 2000). The latter assumes that interventions could be seen as signals of future monetary and exchange rate policy (from monetary authorities with private information about their inflation and exchange rate objectives) and could therefore affect the spot exchange rate by altering exchange rate expectations. The portfolio channel, in turn, works through the imperfect substitutability of local and foreign currency assets that, in the event of a sterilized intervention that modifies the relative supply of local currency assets, should induce a compensating change in cross-asset returns (namely, a depreciation or appreciation consistent with the change in the currency composition of the market portfolio). The nature of domestic financial markets can, a priori, influence the effectiveness of these two channels. For example, emerging market currencies, which are generally regarded as riskier than reserve currencies, face limited levels of cross-currency substitutability, which should strengthen the portfolio channel (Disyatat and Galati, 2005) -an effect that should be further amplified by shallow, illiquid financial markets (Mohanty and Turner, 2005). By contrast, the incidence of the nominal uncertainty and poor track record characteristic of many emerging economies on intervention effectiveness through the signalling channel is ambiguous: it may detract from the impact of intervention on expectations (if monetary policy is seen as erratic and noisy) or enhance it (it policy is perceived as opaque but consistent).

\footnotetext{
${ }^{17}$ Including the large deviation dummies as an additional control does not alter these results. They are not shown here for the sake of brevity but are available upon request.
} 
In order to explore these issues we proceed in two steps. First, we estimate our baseline model allowing for a country-specific intervention coefficient (by interacting intervention with a set of country dummies). Next, we analyse the correlation between this country-specific measure of intervention effectiveness and the average value of financial and macroeconomic variables that capture relevant aspects of the signalling or portfolio channels. More precisely, we proxy currency substitutability with both a measure of "original sin" (OSIN3) -the degree to which countries can borrow abroad in their own currency- computed by Eichengreen, Hausmann and Panizza (2005) as: $\max \left(1-\frac{\text { securities issued in currency } i}{\text { securities issued by country } i}, 0\right)$, and a proxy for financial dollarization (the deposit dollarization ratio compiled in Levy Yeyati, 2006). In turn, we include the average CPI inflation rate as an indicator of the Central Bank's monetary policy track record. Additionally, we test domestic financial development (measured as credit to the private sector over GDP) and two measures of financial openness: a de jure measure of capital account openness from the updated version of Chinn and Ito (2008), and a de facto measure using the sum of external assets and liabilities as a share of GDP based on Lane and Milesi-Ferretti (2007).

The results (shown in Figure 3) indicate that:

i) Intervention effectiveness declines with inflation and financial dollarization. This is a priori consistent with the premise that higher (and more volatile) levels of inflation detract from the central bank's credibility, as a result, from the signalling role of interventions; and with the fact that, in financially dollarized economies, greater substitutability between local and foreign currency assets weakens the portfolio channel. Note that inflation and financial dollarization in emerging economies are themselves connected, since the pass-through from the exchange rate to CPI inflation tends to increase with inflation (see e.g. Mihaljek and Klau, 2008).

ii) Interventions are more effective in countries with more developed financial markets, a result that may be capturing the fact that local market development is generally associated with a greater demand for local currency and lower currency substitution. ${ }^{18}$

iii) Intervention effectiveness does not appear to be correlated with de jure and de facto measures of financial openness.

\footnotetext{
${ }^{18} \mathrm{We}$ also estimated one-step models that include these variables as interaction with the intervention in the original panel regressions, with similar results.
} 
[Insert Figure 3 here]

Is intervention more effective when it is leaning against the global wind? We analyse whether the impact of central bank interventions increases as the global financial cycle intensifies; particularly, we examine whether is more effective to contain depreciation during peaks of global risk aversion (Table 4) or exchange rate pressures (in either direction) fuelled by large swings in the global value of the USD (Table 5), as opposed to foreign exchange sales and purchases in times of "normal" dollar behaviour.

Columns (1) and (2) in Table 4 report estimates for periods where global risk aversion (as proxied by the VIX) is above or below its median. The comparison shows that, overall, interventions seem to be comparable or slightly more effective during periods of reduced global risk appetite. In Column (3) we pool observations and interact the intervention coefficient with a high-riskaversion dummy and find similar results: the point estimate for intervention in risk-off periods is 14 percentage points larger, but this difference is barely statistically significant at $10 \%$. Indeed, when we look at the effectiveness of FX sales during risk aversion episodes (column 4), we do not find a significant difference relative to other periods. Defining risk-off periods slightly differently, as months when global risk aversion increases by more than $10 \%$, we get comparable results (columns 5 to 8 ). In sum, intervention does not seem to be more effective than usual as a tool to counter depreciation pressures due to spells of global risk aversion.

[Insert Table 5 here]

In Table 5, we replicate the exercise for the case of globally-driven exchange rate pressure, captured by large variations in the global value of the USD, where large is defined as log changes of the DXY -the nominal effective exchange rate of the USD against other major developed economies' currencies- is either at the lower decile (a depreciation of at least 2.6\%) or the upper decile (an appreciation of at least 1.8\%) of its sample distribution. This time, the results are more 
convincing: the estimates reported in columns (1) and (2) of Table 5 show that interventions during shocks to the global value of the UD dollar are indeed significantly more effective than otherwise. The effect appears to be symmetric: purchases during USD appreciations and sales during USD depreciations show up with comparable coefficients (column 3). Reassuringly, when we restrict the sample to just USD appreciations and depreciations episodes (column 4 and 5), intervention coefficients are larger than in the whole sample. In sum, there is evidence that leaning against the wind seems to be particularly effective during periods of global dollar depreciation and appreciation.

[Insert Table 6 here]

\section{Conclusions}

In this paper, by defining intervention as changes in the reserve-to-M2 ratio, we showed that exchange rate interventions in EM are generally effective, in the sense that they move the real exchange rate in the desired direction of the intervention. Our findings are robust to endogeneity corrections (indeed, since the reverse causality works against the empirical measure of effectiveness, the use of instrumental variables strengthen the results), as well as to the use of different samples and specifications. We find little evidence of asymmetries related to the direction of intervention (sales vs. purchases) or to the direction of the global shock (global appreciations versus depreciations of the US dollar), and no significant difference in the effectiveness of intervention according to the nature of the trigger (for example, depreciation pressures due to spikes in global risk aversion). We document that interventions tend to be more effective when the real exchange rate exhibits a large deviations from its long run equilibrium level. Regarding the incidence of country characteristics, we find that interventions are less effective in economies with high levels of financial or external liability dollarization (in line with the existence of a portfolio channel) and under high inflation (in line with the signalling channel). The evidence presented here supports the view that central bank intervention can indeed influence the exchange rate in the short run, a premise that, although accepted by most practitioners, had so far received only partial confirmation in the empirical academic literature. In addition, we find 
preliminary evidence consistent with the portfolio and signalling channels highlighted by the theoretical literature, a starting point for further research on the preconditions and the transmission channels of foreign exchange interventions in emerging markets. 
Table 1 - Motives, objectives and tools for FX market interventions reported by Central Banks

\begin{tabular}{|c|c|c|c|c|c|c|}
\hline \multirow[t]{2}{*}{ Motives for Intervention } & \multicolumn{3}{|c|}{ Importance in 2005} & \multicolumn{3}{|c|}{ Importance in 2012-2013 } \\
\hline & High & Moderate & Low & High & Moderate & Low \\
\hline 1. Curb excessive speculation & $42 \%$ & $21 \%$ & $0 \%$ & $60 \%$ & $20 \%$ & $0 \%$ \\
\hline 2. Maintain monetary stability & $36 \%$ & $11 \%$ & $11 \%$ & $55 \%$ & $10 \%$ & $10 \%$ \\
\hline 3. Discourage sharp capital flows & $21 \%$ & $16 \%$ & $5 \%$ & $30 \%$ & $25 \%$ & $5 \%$ \\
\hline 4. Build Reserves & $36 \%$ & $0 \%$ & $11 \%$ & $30 \%$ & $10 \%$ & $10 \%$ \\
\hline 5. Smooth the impact of commodity price movements & $16 \%$ & $5 \%$ & $16 \%$ & $20 \%$ & $5 \%$ & $15 \%$ \\
\hline 6. Maintain or enhance competitiveness & $11 \%$ & $11 \%$ & $16 \%$ & $25 \%$ & $5 \%$ & $15 \%$ \\
\hline Immediate Objectives & 2005 & 2012 & \multirow{2}{*}{\multicolumn{2}{|c|}{\begin{tabular}{|l} 
Intervention Tools \\
Market based
\end{tabular}}} & Regularly & Occasionally \\
\hline 1. Influence the level of the exchange rate & $21 \%$ & $20 \%$ & & & & \\
\hline 2. Smooth the path of the exchange rate & $36 \%$ & $35 \%$ & \multicolumn{2}{|c|}{ 1. Spot market intervention } & $91 \%$ & $9 \%$ \\
\hline 3. Limit Volatility & $57 \%$ & $60 \%$ & \multicolumn{2}{|c|}{ 2. Forward market intervention } & $9 \%$ & $36 \%$ \\
\hline 4. Limit pressures arising from capital flows & $42 \%$ & $45 \%$ & \multicolumn{2}{|c|}{ 3. Use of derivatives } & $14 \%$ & $32 \%$ \\
\hline 5. Provide liquidity to thin exchange rate market & $10 \%$ & $20 \%$ & \multicolumn{2}{|c|}{ Other interventions } & & \\
\hline & & & \multicolumn{2}{|c|}{ 4. Capital Controls } & $12 \%$ & $18 \%$ \\
\hline
\end{tabular}

Note: The results are based on a 2013 BIS survey and a WB survey conducted in 2013. Respondents in these three surveys include: Argentina, Brazil, Chile, Colombia, Czech Republic, Hungary, Hong Kong SAR, Rep. of Korea, India, Indonesia, Malaysia, Mexico, New Zealand, Peru, Philippines, Poland, Singapore, South Africa, Thailand, Turkey, Uruguay, and Venezuela. 
Table 2 - Equilibrium RER as a function of fundamentals

\begin{tabular}{|c|c|c|c|c|c|c|}
\hline Variables & $\begin{array}{c}(1) \\
\text { LAC }\end{array}$ & $\begin{array}{c}(2) \\
\text { ASIA } \\
\end{array}$ & $\begin{array}{c}(3) \\
\text { EMEA }\end{array}$ & $\begin{array}{c}(4) \\
\text { Emerging } \\
\end{array}$ & $\begin{array}{c}(5) \\
\text { Advanced } \\
\end{array}$ & $\begin{array}{r}(6) \\
\text { All } \\
\end{array}$ \\
\hline NFA & $\begin{array}{l}0.406^{* * *} \\
(3.45)\end{array}$ & $\begin{array}{l}-0.113 \\
(-1.27)\end{array}$ & $\begin{array}{l}-0.765^{* * *} \\
(-3.83)\end{array}$ & $\begin{array}{l}-0.120 \\
(-1.53)\end{array}$ & $\begin{array}{l}-0.153^{* * *} \\
(-2.68)\end{array}$ & $\begin{array}{l}-0.146^{* *} \\
(-2.54)\end{array}$ \\
\hline Log(Open) & $\begin{array}{l}-0.784 * * * \\
(-2.83)\end{array}$ & $\begin{array}{l}-0.452^{* * *} \\
(-6.31)\end{array}$ & $\begin{array}{l}-0.688^{* * *} \\
(-4.42)\end{array}$ & $\begin{array}{l}-0.512^{* * *} \\
(-6.53)\end{array}$ & $\begin{array}{l}-0.684 * * * \\
(-10.05)\end{array}$ & $\begin{array}{l}-0.540 * * * \\
(-6.70)\end{array}$ \\
\hline Log(Commodity TOT) & $\begin{array}{l}2.286^{* *} \\
(2.15)\end{array}$ & $\begin{array}{l}-0.360 \\
(-0.60)\end{array}$ & $\begin{array}{l}0.276 \\
(0.58)\end{array}$ & $\begin{array}{l}-0.190 \\
(-0.43)\end{array}$ & $\begin{array}{l}0.154 \\
(0.54)\end{array}$ & $\begin{array}{l}0.243 \\
(0.79)\end{array}$ \\
\hline $\log (\mathrm{G} / \mathrm{GDP})$ & $\begin{array}{l}0.873^{* * *} \\
(6.51)\end{array}$ & $\begin{array}{l}0.455^{* * *} \\
(3.31)\end{array}$ & $\begin{array}{l}0.389 * * \\
(2.43)\end{array}$ & $\begin{array}{l}0.379 * * * \\
(3.21)\end{array}$ & $\begin{array}{l}-0.0313 \\
(-0.21)\end{array}$ & $\begin{array}{l}0.174 \\
(1.37)\end{array}$ \\
\hline Log(Productivity) & $\begin{array}{l}0.769 * * \\
(2.56)\end{array}$ & $\begin{array}{l}0.764 * * * \\
(7.65)\end{array}$ & $\begin{array}{l}0.0587 \\
(0.31)\end{array}$ & $\begin{array}{l}0.735^{* * *} \\
(6.29)\end{array}$ & $\begin{array}{l}0.313 \\
(1.09)\end{array}$ & $\begin{array}{l}0.691 * * * \\
(6.40)\end{array}$ \\
\hline $\begin{array}{l}\mathrm{N} \\
\text { Countries } \\
\text { R-sq Within }\end{array}$ & $\begin{array}{l}325 \\
5 \\
0.6915\end{array}$ & $\begin{array}{l}390 \\
6 \\
0.7321\end{array}$ & $\begin{array}{l}455 \\
7 \\
0.7536\end{array}$ & $\begin{array}{l}1170 \\
18 \\
0.6226\end{array}$ & $\begin{array}{l}715 \\
11 \\
0.6445\end{array}$ & $\begin{array}{l}1885 \\
29 \\
0.5889\end{array}$ \\
\hline
\end{tabular}

Note: LAC includes Brazil, Chile, Colombia, Mexico, and Peru; Asia includes India, Indonesia, Rep. of Korea, Malaysia, Philippines, and Thailand; EMEA includes Czech Republic, Hungary, Poland, Rumania, Russia, South Africa and Turkey; Advanced includes Australia, Canada, Israel, Japan, New Zealand, Norway, Singapore, Sweden, Switzerland, and UK. Estimated based on a dynamic OLS specification. $t$ statistics in parentheses using clustered standard errors at the country level. The asterisks indicate statistical significance, ${ }^{*} p<0.10,{ }^{* *} p<0.05,{ }^{* * *} p<0.01$. Source: Daude et al. (2013). 
Table 3 - Baseline estimates and bias-corrected estimates

\begin{tabular}{|c|c|c|c|c|c|c|c|c|}
\hline & (1) & (2) & (3) & (4) & (5) & (6) & (7) & (8) \\
\hline Estimation Method & LSDV & LSDV & LSDV & LSDV & LSDVC & LSDVC & LSDVC & LSDVC \\
\hline Lagged Dep. variable & $\begin{array}{r}0.122 \\
(0.039)^{* * *}\end{array}$ & $\begin{array}{c}0.139 \\
(0.036)^{* * *}\end{array}$ & $\begin{array}{c}0.121 \\
(0.039)^{* * *}\end{array}$ & $\begin{array}{c}0.132 \\
(0.036)^{* * *}\end{array}$ & $\begin{array}{c}0.138 \\
(0.024)^{* * *}\end{array}$ & $\begin{array}{c}0.155 \\
(0.024)^{* * *}\end{array}$ & $\begin{array}{c}0.137 \\
(0.024)^{* * *}\end{array}$ & $\begin{array}{c}0.148 \\
(0.024)^{* * *}\end{array}$ \\
\hline Error correction equilibrium RER (t-1) & $\begin{array}{r}-0.032 \\
(0.007)^{* * *}\end{array}$ & $\begin{array}{c}-0.026 \\
(0.007)^{* * *}\end{array}$ & $\begin{array}{c}-0.032 \\
(0.007)^{* * *}\end{array}$ & $\begin{array}{c}-0.025 \\
(0.007)^{* * *}\end{array}$ & $\begin{array}{c}-0.017 \\
(0.021)\end{array}$ & $\begin{array}{c}-0.011 \\
(0.020)\end{array}$ & $\begin{array}{c}-0.017 \\
(0.021)\end{array}$ & $\begin{array}{c}-0.010 \\
(0.020)\end{array}$ \\
\hline$\triangle N F A$ & $\begin{array}{r}0.127 \\
(0.034)^{* * *}\end{array}$ & $\begin{array}{c}0.125 \\
(0.038)^{* * *}\end{array}$ & $\begin{array}{c}0.121 \\
(0.033)^{* * *}\end{array}$ & $\begin{array}{c}0.103 \\
(0.042)^{* *}\end{array}$ & $\begin{array}{r}0.095 \\
(0.219)\end{array}$ & $\begin{array}{c}0.094 \\
(0.210)\end{array}$ & $\begin{array}{r}0.089 \\
(0.219)\end{array}$ & $\begin{array}{r}0.073 \\
(0.211)\end{array}$ \\
\hline$\Delta$ Trade Openness (logs) & $\begin{array}{r}-0.549 \\
(0.055)^{* * *}\end{array}$ & $\begin{array}{c}-0.476 \\
(0.039)^{* * *}\end{array}$ & $\begin{array}{c}-0.545 \\
(0.056)^{* * *}\end{array}$ & $\begin{array}{c}-0.473 \\
(0.038)^{* * *}\end{array}$ & $\begin{array}{c}-0.538 \\
(0.125)^{* * *}\end{array}$ & $\begin{array}{c}-0.465 \\
(0.121)^{* * *}\end{array}$ & $\begin{array}{c}-0.534 \\
(0.125)^{* * *}\end{array}$ & $\begin{array}{c}-0.462 \\
(0.122)^{* * *}\end{array}$ \\
\hline$\Delta$ Government consumption (logs) & $\begin{array}{r}0.039 \\
(0.029)\end{array}$ & $\begin{array}{r}0.029 \\
(0.028)\end{array}$ & $\begin{array}{r}0.038 \\
(0.028)\end{array}$ & $\begin{array}{r}0.026 \\
(0.027)\end{array}$ & $\begin{array}{r}0.041 \\
(0.105)\end{array}$ & $\begin{array}{c}0.032 \\
(0.101)\end{array}$ & $\begin{array}{r}0.041 \\
(0.105)\end{array}$ & $\begin{array}{r}0.028 \\
(0.100)\end{array}$ \\
\hline$\Delta$ Productivity (logs) & $\begin{array}{r}-0.075 \\
(0.012)^{* * *}\end{array}$ & $\begin{array}{c}-0.073 \\
(0.012)^{* * *}\end{array}$ & $\begin{array}{c}-0.074 \\
(0.012)^{* * *}\end{array}$ & $\begin{array}{c}-0.070 \\
(0.013)^{* * *}\end{array}$ & $\begin{array}{c}-0.064 \\
(0.188)\end{array}$ & $\begin{array}{c}-0.061 \\
(0.180)\end{array}$ & $\begin{array}{c}-0.063 \\
(0.187)\end{array}$ & $\begin{array}{l}-0.059 \\
(0.179)\end{array}$ \\
\hline$\Delta \mathrm{VIX}$ & $\begin{array}{r}-0.001 \\
(0.000)^{* * *}\end{array}$ & $\begin{array}{c}-0.001 \\
(0.000)^{* * *}\end{array}$ & $\begin{array}{c}-0.001 \\
(0.000)^{* * *}\end{array}$ & $\begin{array}{c}-0.001 \\
(0.000)^{* * *}\end{array}$ & $\begin{array}{c}-0.001 \\
(0.000)^{* *}\end{array}$ & $\begin{array}{c}-0.001 \\
(0.000)^{* *}\end{array}$ & $\begin{array}{c}-0.001 \\
(0.000)^{* *}\end{array}$ & $\begin{array}{c}-0.001 \\
(0.000)^{* *}\end{array}$ \\
\hline Carry USD & $\begin{array}{r}-0.001 \\
(0.000)\end{array}$ & $\begin{array}{c}-0.000 \\
(0.000)\end{array}$ & $\begin{array}{c}-0.001 \\
(0.000)\end{array}$ & $\begin{array}{r}-0.000 \\
(0.000)\end{array}$ & $\begin{array}{c}-0.000 \\
(0.001)\end{array}$ & $\begin{array}{c}-0.000 \\
(0.001)\end{array}$ & $\begin{array}{c}-0.000 \\
(0.001)\end{array}$ & $\begin{array}{c}-0.000 \\
(0.001)\end{array}$ \\
\hline$(\mathrm{R} / \mathrm{M} 2)(\mathrm{t})-(\mathrm{R} / \mathrm{M} 2)(\mathrm{t}-1)$ & $\begin{array}{r}-0.184 \\
(0.065)^{* *}\end{array}$ & & $\begin{array}{c}-0.241 \\
(0.100)^{* *}\end{array}$ & & $\begin{array}{c}-0.184 \\
(0.090)^{* *}\end{array}$ & & $\begin{array}{l}-0.241 \\
(0.156)\end{array}$ & \\
\hline Instrumented Intervention & & $\begin{array}{c}-0.544 \\
(0.158)^{* * *}\end{array}$ & & $\begin{array}{c}-0.689 \\
(0.179)^{* * *}\end{array}$ & & $\begin{array}{c}-0.545 \\
(0.142)^{* * *}\end{array}$ & & $\begin{array}{c}-0.688 \\
(0.216)^{* * *}\end{array}$ \\
\hline Sales of reserves & & & $\begin{array}{c}0.109 \\
(0.086)\end{array}$ & & & & $\begin{array}{c}0.107 \\
(0.243)\end{array}$ & \\
\hline Instrumented sales of reserves & & & & $\begin{array}{c}0.302 \\
(0.078)^{* * *}\end{array}$ & & & & $\begin{array}{c}0.298 \\
(0.314)\end{array}$ \\
\hline$R^{2}$ & 0.26 & 0.31 & 0.27 & 0.32 & & & & \\
\hline$N$ & 1,679 & 1,679 & 1,679 & 1,679 & 1,670 & 1,670 & 1,670 & 1,670 \\
\hline
\end{tabular}

$* p<0.1 ; * * p<0.05 ; * * * p<0.01$. Depedent variable: first log difference of the real exchange rate. All regressions include country dummies. Robust standard errors in parenthesis for (1) - (4). Bootstrapped standard errors (500 reps) for (5) - (8). 
Table 4 - Robustness: Sample, regions, large deviations from equilibrium RER and sales versus purchases

\begin{tabular}{|c|c|c|c|c|c|c|c|c|c|c|}
\hline & $\begin{array}{l}\text { Restricted } \\
\text { Sample }\end{array}$ & $\begin{array}{l}\text { Restricted } \\
\text { Sample }\end{array}$ & $\begin{array}{l}\text { Restricted } \\
\text { Sample }\end{array}$ & $\begin{array}{l}\text { Restricted } \\
\text { Sample }\end{array}$ & $\begin{array}{l}\text { Regional } \\
\text { estimates }\end{array}$ & $\begin{array}{l}\text { Regional }^{1} \\
\text { estimates }\end{array}$ & $\begin{array}{l}\text { Deviation } \\
\text { from ERER }\end{array}$ & $\begin{array}{l}\text { Deviation }^{1} \\
\text { from ERER }\end{array}$ & $\begin{array}{l}\text { Sales vs. } \\
\text { purchases }\end{array}$ & $\begin{array}{l}\text { Sales }^{1} \text { vs. } \\
\text { purchases }\end{array}$ \\
\hline \multirow[t]{2}{*}{ Lagged Dep. variable } & 0.135 & 0.154 & 0.136 & 0.156 & 0.141 & 0.160 & 0.137 & 0.152 & 0.135 & 0.152 \\
\hline & $(0.038)^{* * *}$ & $(0.040)^{* * *}$ & $(0.038)^{* * *}$ & $(0.041)^{* * *}$ & $(0.037)^{* * *}$ & $(0.047)^{* * *}$ & $(0.035)^{* * *}$ & $(0.039)^{* * *}$ & $(0.035)^{* * *}$ & $(0.039)^{* * *}$ \\
\hline \multirow[t]{2}{*}{ ECM equilibrium RER (t-1) } & -0.029 & -0.024 & -0.030 & -0.024 & -0.027 & -0.027 & -0.024 & -0.021 & -0.024 & -0.020 \\
\hline & $(0.008)^{* * *}$ & $(0.008)^{* * *}$ & $(0.008)^{* * *}$ & $(0.008)^{* *}$ & $(0.006)^{* * *}$ & $(0.008)^{* * *}$ & $(0.007)^{* * *}$ & $(0.008)^{* *}$ & $(0.006)^{* * *}$ & $(0.008) * *$ \\
\hline \multirow[t]{2}{*}{$\triangle \mathrm{NFA}$} & -0.007 & 0.019 & -0.005 & 0.024 & 0.122 & 0.040 & 0.123 & 0.033 & 0.099 & 0.035 \\
\hline & $(0.093)$ & $(0.091)$ & $(0.090)$ & $(0.088)$ & $(0.039)^{* * *}$ & $(0.091)$ & $(0.042)^{* * *}$ & $(0.090)$ & $(0.044)^{* *}$ & $(0.087)$ \\
\hline \multirow[t]{2}{*}{$\Delta$ Openness (logs) } & -0.514 & -0.456 & -0.516 & -0.457 & -0.473 & -0.453 & -0.474 & -0.455 & -0.475 & -0.455 \\
\hline & $(0.080)^{* * *}$ & $(0.070)^{* * *}$ & $(0.081)^{* * *}$ & $(0.070)^{* * *}$ & $(0.041)^{* * *}$ & $(0.073)^{* * *}$ & $(0.041)^{* * *}$ & $(0.068)^{* * *}$ & $(0.041)^{* * *}$ & $(0.068)^{* * *}$ \\
\hline \multirow[t]{2}{*}{$\Delta$ Govt. consumption (logs) } & 0.048 & 0.038 & 0.048 & 0.040 & 0.031 & 0.043 & 0.028 & 0.035 & 0.024 & 0.035 \\
\hline & $(0.016)^{* * *}$ & $(0.019)^{*}$ & $(0.016)^{* * *}$ & $(0.020)^{*}$ & $(0.029)$ & $(0.019)^{* *}$ & $(0.027)$ & $(0.019)^{*}$ & $(0.025)$ & $(0.020)^{*}$ \\
\hline \multirow[t]{2}{*}{$\Delta$ Productivity (logs) } & -0.192 & -0.192 & -0.191 & -0.192 & -0.070 & -0.184 & -0.072 & -0.200 & -0.063 & -0.201 \\
\hline & $(0.024)^{* * *}$ & $(0.024)^{* * *}$ & $(0.024)^{* * *}$ & $(0.024)^{* * *}$ & $(0.014)^{* * *}$ & $(0.027)^{* * *}$ & $(0.012)^{* * *}$ & $(0.025)^{* * *}$ & $(0.015)^{* * *}$ & $(0.025)^{* * *}$ \\
\hline \multirow[t]{2}{*}{$\Delta \mathrm{VIX}$} & -0.000 & -0.000 & -0.000 & -0.000 & -0.001 & -0.000 & -0.001 & -0.000 & -0.001 & -0.000 \\
\hline & $(0.000)^{* *}$ & $(0.000)^{* *}$ & $(0.000)^{* *}$ & $(0.000)^{* *}$ & $(0.000)^{* * *}$ & $(0.000)^{* *}$ & $(0.000)^{* * *}$ & $(0.000)^{* *}$ & $(0.000)^{* * *}$ & $(0.000)^{* *}$ \\
\hline \multirow[t]{2}{*}{ Carry USD } & -0.000 & -0.000 & -0.000 & -0.000 & -0.000 & -0.000 & -0.000 & -0.000 & -0.000 & -0.000 \\
\hline & $(0.000)$ & $(0.000)$ & $(0.000)$ & $(0.000)$ & $(0.000)$ & $(0.000)$ & $(0.000)$ & $(0.000)$ & $(0.000)$ & $(0.000)$ \\
\hline \multirow[t]{2}{*}{$(\mathrm{R} / \mathrm{M} 2)(\mathrm{t})-(\mathrm{R} / \mathrm{M} 2)(\mathrm{t}-1)$} & -0.073 & & -0.048 & & & & & & & \\
\hline & $(0.026)^{* *}$ & & $(0.047)$ & & & & & & & \\
\hline \multirow[t]{2}{*}{ Instrumented Intervention } & & -0.390 & & -0.345 & -0.673 & -0.392 & -0.476 & -0.302 & -0.471 & -0.301 \\
\hline & & $(0.134)^{* *}$ & & $(0.134)^{* *}$ & $(0.295)^{* *}$ & $(0.141)^{* *}$ & $(0.174)^{* *}$ & $(0.130)^{* *}$ & $(0.173)^{* *}$ & $(0.130)^{* *}$ \\
\hline Sales of reserves & & & $\begin{array}{c}-0.048 \\
(0.082)\end{array}$ & & & & & & & \\
\hline \multirow[t]{2}{*}{ Instrumented sales of res. } & & & & -0.118 & & & & & & \\
\hline & & & & $(0.140)$ & & & & & & \\
\hline \multirow[t]{2}{*}{ LAC dummy x Instr. Int. } & & & & & 0.356 & 0.143 & & & & \\
\hline & & & & & $(0.359)$ & $(0.180)$ & & & & \\
\hline \multirow[t]{2}{*}{ EMEA dummy $x$ Instr. Int. } & & & & & -0.117 & -0.274 & & & & \\
\hline & & & & & $(0.333)$ & $(0.316)$ & & & & \\
\hline \multirow[t]{2}{*}{ Instr. Int. x large dev. ERER } & & & & & & & -0.225 & -0.352 & & \\
\hline & & & & & & & $(0.163)$ & $(0.100)^{* * *}$ & & \\
\hline \multirow[t]{2}{*}{ Instr. Sales $x$ large dev. ERER } & & & & & & & & & 0.133 & -0.432 \\
\hline & & & & & & & & & $(0.198)$ & $(0.222)^{*}$ \\
\hline \multirow[t]{2}{*}{ Instr. Purch. $x$ large dev ERER } & & & & & & & & & -0.543 & -0.314 \\
\hline & & & & & & & & & $(0.166)^{* * *}$ & $(0.128)^{* *}$ \\
\hline$R^{2}$ & 0.22 & 0.25 & 0.22 & 0.25 & 0.33 & 0.26 & 0.32 & 0.26 & 0.33 & 0.26 \\
\hline$N$ & 1027 & 1027 & 1027 & 1027 & 1679 & 1027 & 1679 & 1027 & 1679 & 1027 \\
\hline
\end{tabular}

See Table 1 for details. The restricted sample are observations for which the change in reserves has the same sign as the intervention variable. ${ }^{1}$ restricted sample only. 
Table 5 - The effectiveness of FX intervention and global risk aversion shocks

\begin{tabular}{|c|c|c|c|c|c|c|c|c|}
\hline & (1) & (2) & (3) & (4) & (5) & (6) & (7) & (8) \\
\hline & $\begin{array}{l}\text { High VIX } \\
\text { sample }\end{array}$ & $\begin{array}{c}\text { Low VIX } \\
\text { sample }\end{array}$ & Full sample & Full sample & $\Delta \mathrm{VIX}>10 \%$ & $\Delta \mathrm{VIX}<=10 \%$ & Full sample & Full sample \\
\hline Lagged Dep. variable & $\begin{array}{c}0.119 \\
(0.048)^{* *}\end{array}$ & $\begin{array}{c}0.158 \\
(0.043)^{* * *}\end{array}$ & $\begin{array}{c}0.136 \\
(0.036)^{* * *}\end{array}$ & $\begin{array}{c}0.132 \\
(0.036)^{* * *}\end{array}$ & $\begin{array}{c}0.095 \\
(0.069)\end{array}$ & $\begin{array}{c}0.125 \\
(0.032)^{* * *}\end{array}$ & $\begin{array}{c}0.138 \\
(0.036)^{* * *}\end{array}$ & $\begin{array}{c}0.132 \\
(0.036)^{* * *}\end{array}$ \\
\hline ECM equilibrium RER ( $t-1)$ & $\begin{array}{c}-0.039 \\
(0.014)^{* *}\end{array}$ & $\begin{array}{c}-0.027 \\
(0.011)^{* *}\end{array}$ & $\begin{array}{c}-0.026 \\
(0.007)^{* * *}\end{array}$ & $\begin{array}{c}-0.025 \\
(0.007)^{* * *}\end{array}$ & $\begin{array}{c}-0.029 \\
(0.011)^{* *}\end{array}$ & $\begin{array}{c}-0.026 \\
(0.008)^{* * *}\end{array}$ & $\begin{array}{c}-0.025 \\
(0.007)^{* * *}\end{array}$ & $\begin{array}{c}-0.025 \\
(0.007)^{* * *}\end{array}$ \\
\hline$\triangle \mathrm{NFA}$ & $\begin{array}{c}0.085 \\
(0.058)\end{array}$ & $\begin{array}{c}0.237 \\
(0.065)^{* * *}\end{array}$ & $\begin{array}{c}0.123 \\
(0.038)^{* * *}\end{array}$ & $\begin{array}{c}0.104 \\
(0.041)^{* *}\end{array}$ & $\begin{array}{l}-0.006 \\
(0.120)\end{array}$ & $\begin{array}{c}0.151 \\
(0.070)^{* *}\end{array}$ & $\begin{array}{c}0.121 \\
(0.039)^{* * *}\end{array}$ & $\begin{array}{c}0.104 \\
(0.042)^{* *}\end{array}$ \\
\hline$\Delta$ Openness (logs) & $\begin{array}{c}-0.494 \\
(0.065)^{* * *}\end{array}$ & $\begin{array}{c}-0.398 \\
(0.058)^{* * *}\end{array}$ & $\begin{array}{c}-0.479 \\
(0.040)^{* * *}\end{array}$ & $\begin{array}{c}-0.473 \\
(0.038)^{* * *}\end{array}$ & $\begin{array}{c}-0.536 \\
(0.075)^{* * *}\end{array}$ & $\begin{array}{c}-0.458 \\
(0.054)^{* * *}\end{array}$ & $\begin{array}{c}-0.480 \\
(0.040)^{* * *}\end{array}$ & $\begin{array}{c}-0.473 \\
(0.038)^{* * *}\end{array}$ \\
\hline$\Delta$ Govt. consumption (logs) & $\begin{array}{l}-0.022 \\
(0.049)\end{array}$ & $\begin{array}{c}0.060 \\
(0.032)^{*}\end{array}$ & $\begin{array}{c}0.029 \\
(0.028)\end{array}$ & $\begin{array}{c}0.026 \\
(0.027)\end{array}$ & $\begin{array}{c}0.124 \\
(0.077)\end{array}$ & $\begin{array}{c}0.009 \\
(0.023)\end{array}$ & $\begin{array}{c}0.027 \\
(0.027)\end{array}$ & $\begin{array}{c}0.026 \\
(0.027)\end{array}$ \\
\hline$\Delta$ Productivity (logs) & $\begin{array}{c}-0.089 \\
(0.019)^{* * *}\end{array}$ & $\begin{array}{l}-0.078 \\
(0.044)^{*}\end{array}$ & $\begin{array}{c}-0.074 \\
(0.013)^{* * *}\end{array}$ & $\begin{array}{c}-0.070 \\
(0.013)^{* * *}\end{array}$ & $\begin{array}{c}-0.200 \\
(0.036)^{* * *}\end{array}$ & $\begin{array}{l}-0.021 \\
(0.014)\end{array}$ & $\begin{array}{c}-0.073 \\
(0.012)^{* * *}\end{array}$ & $\begin{array}{c}-0.070 \\
(0.013)^{* * *}\end{array}$ \\
\hline$\Delta \mathrm{VIX}$ & $\begin{array}{c}-0.001 \\
(0.000)^{* *}\end{array}$ & $\begin{array}{c}-0.001 \\
(0.000)^{* * *}\end{array}$ & $\begin{array}{c}-0.001 \\
(0.000)^{* * *}\end{array}$ & $\begin{array}{c}-0.001 \\
(0.000)^{* * *}\end{array}$ & $\begin{array}{c}-0.001 \\
(0.000)^{* *}\end{array}$ & $\begin{array}{l}-0.000 \\
(0.000)\end{array}$ & $\begin{array}{c}-0.001 \\
(0.000)^{* * *}\end{array}$ & $\begin{array}{c}-0.001 \\
(0.000)^{* * *}\end{array}$ \\
\hline Carry USD & $\begin{array}{l}-0.000 \\
(0.001)\end{array}$ & $\begin{array}{l}-0.000 \\
(0.000)^{*}\end{array}$ & $\begin{array}{l}-0.000 \\
(0.000)\end{array}$ & $\begin{array}{l}-0.000 \\
(0.000)\end{array}$ & $\begin{array}{c}-0.001 \\
(0.000)^{* *}\end{array}$ & $\begin{array}{l}-0.000 \\
(0.000)\end{array}$ & $\begin{array}{l}-0.000 \\
(0.000)\end{array}$ & $\begin{array}{l}-0.000 \\
(0.000)\end{array}$ \\
\hline Instrumented Intervention & $\begin{array}{c}-0.580 \\
(0.170)^{* * *}\end{array}$ & $\begin{array}{c}-0.480 \\
(0.157)^{* * *}\end{array}$ & $\begin{array}{c}-0.446 \\
(0.150)^{* * *}\end{array}$ & $\begin{array}{c}-0.689 \\
(0.179)^{* * *}\end{array}$ & $\begin{array}{c}-0.629 \\
(0.195)^{* * *}\end{array}$ & $\begin{array}{c}-0.498 \\
(0.132)^{* * *}\end{array}$ & $\begin{array}{c}-0.491 \\
(0.143)^{* * *}\end{array}$ & $\begin{array}{c}-0.689 \\
(0.179)^{* * *}\end{array}$ \\
\hline Instr. Intervention x High VIX & & & $\begin{array}{l}-0.138 \\
(0.069)^{*}\end{array}$ & & & & & \\
\hline Instrumented sales of reserves & & & & $\begin{array}{c}0.322 \\
(0.133)^{* *}\end{array}$ & & & & $\begin{array}{c}0.315 \\
(0.086)^{* * *}\end{array}$ \\
\hline Instrumented sales $x$ High VIX & & & & $\begin{array}{l}-0.030 \\
(0.124)\end{array}$ & & & & \\
\hline Large $\Delta \mathrm{VIX} \times$ Instr. Intervention & & & & & & & $\begin{array}{c}-0.159 \\
(0.069)^{* *}\end{array}$ & \\
\hline Large $\Delta \mathrm{VIX} \times$ Instr. Sales of reserves & & & & & & & & $\begin{array}{l}-0.056 \\
(0.084)\end{array}$ \\
\hline Constant & $\begin{array}{c}0.000 \\
(0.001)\end{array}$ & $\begin{array}{c}0.002 \\
(0.000)^{* * *}\end{array}$ & $\begin{array}{c}0.001 \\
(0.000)^{* * *}\end{array}$ & $\begin{array}{c}0.002 \\
(0.000)^{* * *}\end{array}$ & $\begin{array}{c}0.002 \\
(0.002)\end{array}$ & $\begin{array}{c}0.002 \\
(0.000)^{* * *}\end{array}$ & $\begin{array}{c}0.001 \\
(0.000)^{* * *}\end{array}$ & $\begin{array}{c}0.002 \\
(0.000)^{* * *}\end{array}$ \\
\hline$R^{2}$ & 0.36 & 0.22 & 0.32 & 0.32 & 0.35 & 0.27 & 0.32 & 0.32 \\
\hline$N$ & 828 & 851 & 1,679 & 1,679 & 413 & 1,266 & 1,679 & 1,679 \\
\hline
\end{tabular}


Table 6 - The effectiveness of FX intervention and USD shocks

\begin{tabular}{|c|c|c|c|c|c|}
\hline & (1) & (2) & (3) & $\begin{array}{c}\text { (4) } \\
\text { Large USD } \\
\text { Appreciations }\end{array}$ & $\begin{array}{c}\text { (5) } \\
\text { Large USD } \\
\text { Depreciations }\end{array}$ \\
\hline Lagged Dep. variable & $\begin{array}{c}0.118 \\
(0.040)^{* * *}\end{array}$ & $\begin{array}{r}0.135 \\
(0.037)^{* * *}\end{array}$ & $\begin{array}{c}0.114 \\
(0.041)^{* *}\end{array}$ & $\begin{array}{c}0.024 \\
(0.110)\end{array}$ & $\begin{array}{r}0.235 \\
(0.088)^{* *}\end{array}$ \\
\hline ECM equilibrium RER (t-1) & $\begin{array}{c}-0.032 \\
(0.007)^{* * *}\end{array}$ & $\begin{array}{c}-0.025 \\
(0.007)^{* * *}\end{array}$ & $\begin{array}{c}-0.030 \\
(0.006)^{* * *}\end{array}$ & $\begin{array}{c}-0.028 \\
(0.015)^{*}\end{array}$ & $\begin{array}{r}-0.038 \\
(0.015)^{* *}\end{array}$ \\
\hline$\triangle \mathrm{NFA}$ & $\begin{array}{r}0.111 \\
(0.034)^{* * *}\end{array}$ & $\begin{array}{c}0.108 \\
(0.042)^{* *}\end{array}$ & $\begin{array}{c}0.082 \\
(0.037)^{* *}\end{array}$ & $\begin{array}{c}0.252 \\
(0.181)\end{array}$ & $\begin{array}{r}0.189 \\
(0.209)\end{array}$ \\
\hline$\Delta$ Openness (logs) & $\begin{array}{c}-0.541 \\
(0.054)^{* * *}\end{array}$ & $\begin{array}{c}-0.479 \\
(0.039)^{* * *}\end{array}$ & $\begin{array}{c}-0.534 \\
(0.052)^{* * *}\end{array}$ & $\begin{array}{c}-0.595 \\
(0.110)^{* * *}\end{array}$ & $\begin{array}{r}-0.352 \\
(0.116)^{* * *}\end{array}$ \\
\hline$\Delta$ Govt. consumption (logs) & $\begin{array}{c}0.030 \\
(0.028)\end{array}$ & $\begin{array}{c}0.025 \\
(0.027)\end{array}$ & $\begin{array}{c}0.033 \\
(0.027)\end{array}$ & $\begin{array}{c}0.013 \\
(0.135)\end{array}$ & $\begin{array}{c}0.069 \\
(0.064)\end{array}$ \\
\hline$\Delta$ Productivity (logs) & $\begin{array}{c}-0.075 \\
(0.013)^{* * *}\end{array}$ & $\begin{array}{c}-0.073 \\
(0.013)^{* * *}\end{array}$ & $\begin{array}{c}-0.073 \\
(0.014)^{* * *}\end{array}$ & $\begin{array}{c}-0.084 \\
(0.042)^{*}\end{array}$ & $\begin{array}{c}-0.284 \\
(0.121)^{* *}\end{array}$ \\
\hline$\Delta \mathrm{VIX}$ & $\begin{array}{c}-0.001 \\
(0.000)^{* * *}\end{array}$ & $\begin{array}{c}-0.001 \\
(0.000)^{* * *}\end{array}$ & $\begin{array}{c}-0.000 \\
(0.000)^{* * *}\end{array}$ & $\begin{array}{c}-0.001 \\
(0.001)^{*}\end{array}$ & $\begin{array}{l}-0.000 \\
(0.000)\end{array}$ \\
\hline Carry USD & $\begin{array}{l}-0.000 \\
(0.000)\end{array}$ & $\begin{array}{l}-0.000 \\
(0.000)\end{array}$ & $\begin{array}{l}-0.000 \\
(0.000)\end{array}$ & $\begin{array}{l}-0.001 \\
(0.001)\end{array}$ & $\begin{array}{l}-0.000 \\
(0.000)\end{array}$ \\
\hline Intervention $=(\mathrm{R} / \mathrm{M} 2)(\mathrm{t})-(\mathrm{R} / \mathrm{M} 2)(\mathrm{t}-1)$ & $\begin{array}{c}-0.138 \\
(0.054)^{* *}\end{array}$ & & $\begin{array}{c}-0.136 \\
(0.053)^{* *}\end{array}$ & & \\
\hline USD shock $\mathrm{x}$ Intervention & $\begin{array}{c}-0.242 \\
(0.085)^{* *}\end{array}$ & & & & \\
\hline Instrumented Intervention & & $\begin{array}{c}-0.454 \\
(0.142)^{* * *}\end{array}$ & & $\begin{array}{c}-0.662 \\
(0.217)^{* * *}\end{array}$ & $\begin{array}{r}-0.730 \\
(0.235)^{* * *}\end{array}$ \\
\hline USD shock $\mathrm{x}$ Instrumented Intervention & & $\begin{array}{c}-0.294 \\
(0.089)^{* * *}\end{array}$ & & & \\
\hline USD shock appreciation $x$ Sales of FX & & & $\begin{array}{c}-0.206 \\
(0.063)^{* * *}\end{array}$ & & \\
\hline USD shock depreciation $\times$ Purchases of FX & & & $\begin{array}{c}-0.232 \\
(0.127)^{*}\end{array}$ & & \\
\hline USD appreciation dummy & & & $\begin{array}{c}-0.007 \\
(0.003)^{* *}\end{array}$ & & \\
\hline USD depreciation dummy & & & $\begin{array}{l}-0.002 \\
(0.002)\end{array}$ & & \\
\hline$R^{2}$ & 0.27 & 0.32 & 0.28 & 0.41 & 0.44 \\
\hline$N$ & 1,679 & 1,679 & 1,679 & 178 & 161 \\
\hline
\end{tabular}


Figure 1: Effective Real Exchange Rates and equilibrium estimates by country

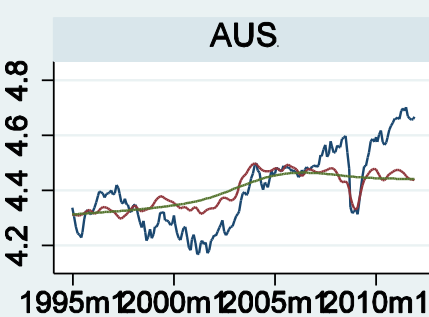

ISL

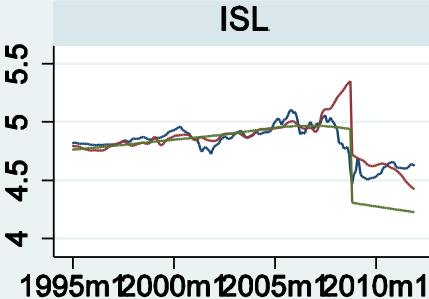

NZL

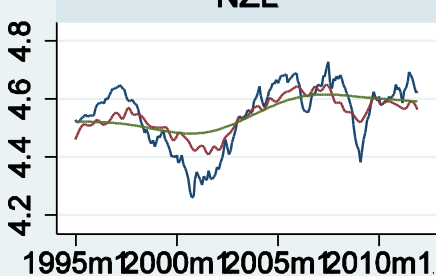

$1995 \mathrm{~m}$ R000m 2005m 2010m1

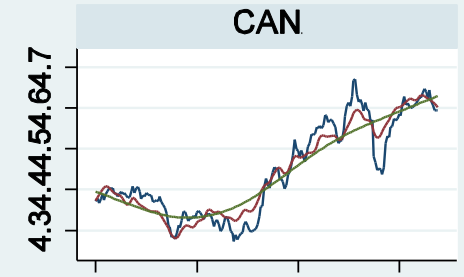

$1995 \mathrm{~m} 12000 \mathrm{~m} 2005 \mathrm{~m} 2010 \mathrm{~m} 1$

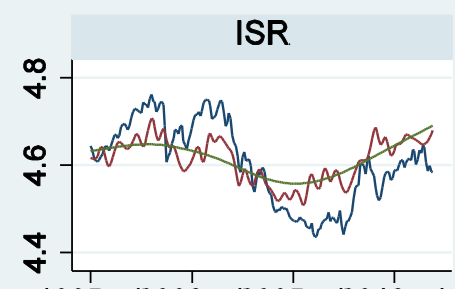

$1995 \mathrm{~m} 2000 \mathrm{~m} 2005 \mathrm{mR010m1}$

SGP

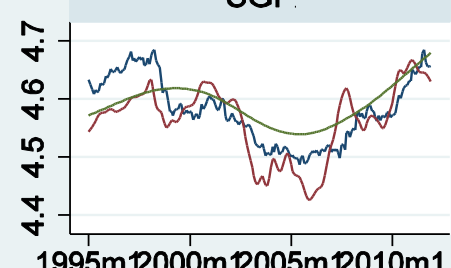

CHE
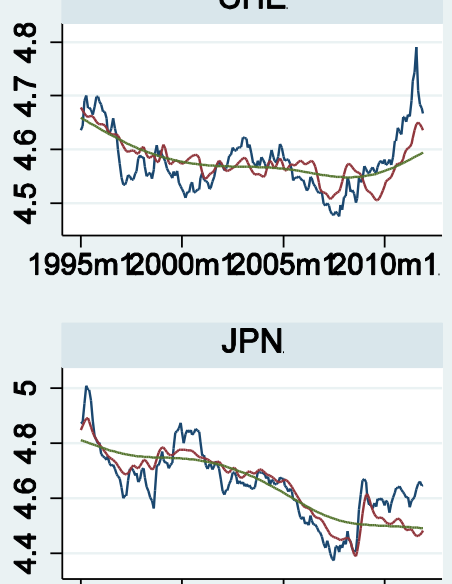

$1995 \mathrm{~m} 2000 \mathrm{~m} 12005 \mathrm{~m}$ R010m1

SWE

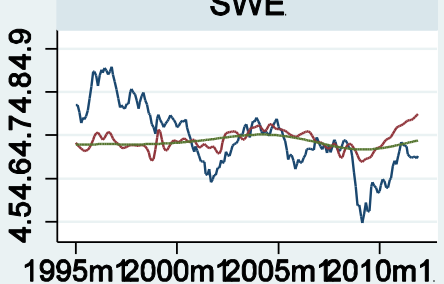

GBR

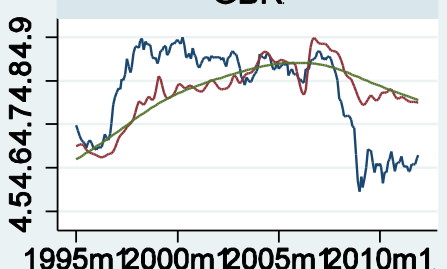

NOR

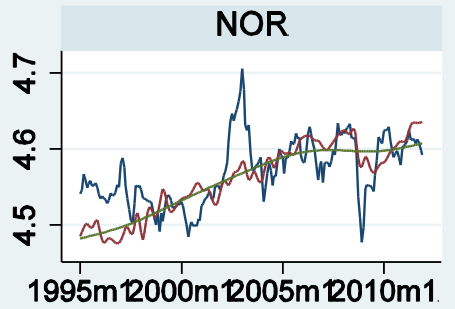

\section{date}

\section{RER}

equilibrium RER

\section{equilibrium RER (HP filtered fundamentals)}

Graphs by countries 
Figure 1: Effective Real Exchange Rates and equilibrium estimates by country (continued)
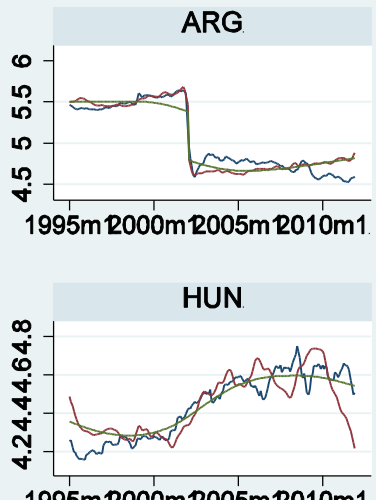

$1995 \mathrm{~m} \mathrm{R000m} \mathrm{R005m} \mathrm{R010m1}$

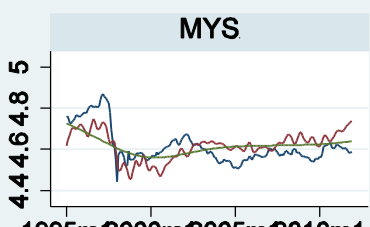

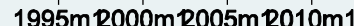

RUS

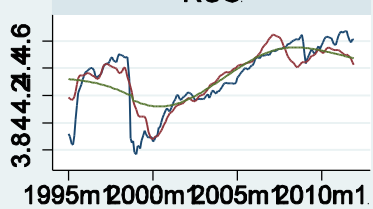

$1995 \mathrm{~m} 2000 \mathrm{mp005mR010 \textrm {m } 1}$

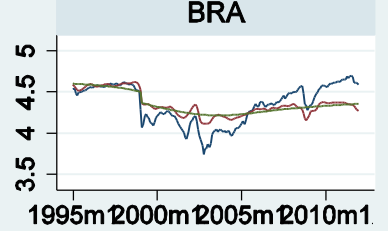

IDN

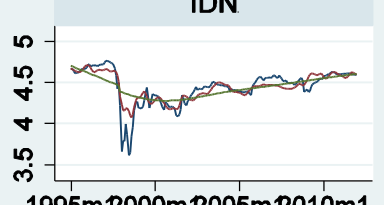

$1995 \mathrm{~m}$ R000m R005m R010m1

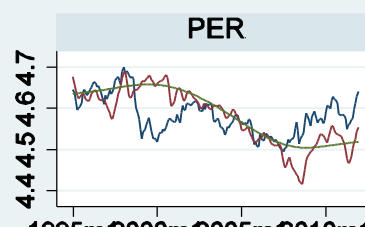

$1995 \mathrm{mP000m} 2005 \mathrm{mR010 \textrm {m }}$

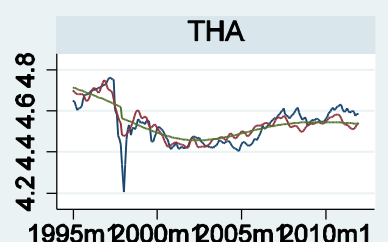

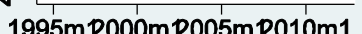

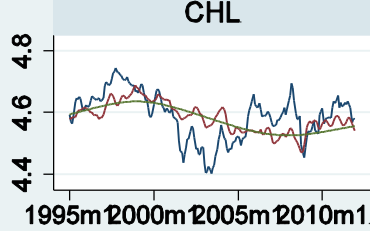

IND
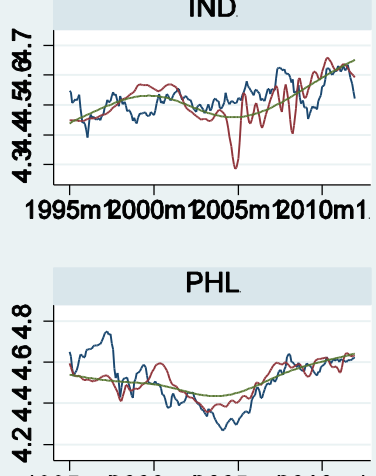

$1995 \mathrm{mR000m} \mathrm{R005m} \mathrm{R010m1}$

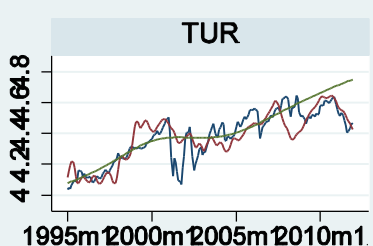

date
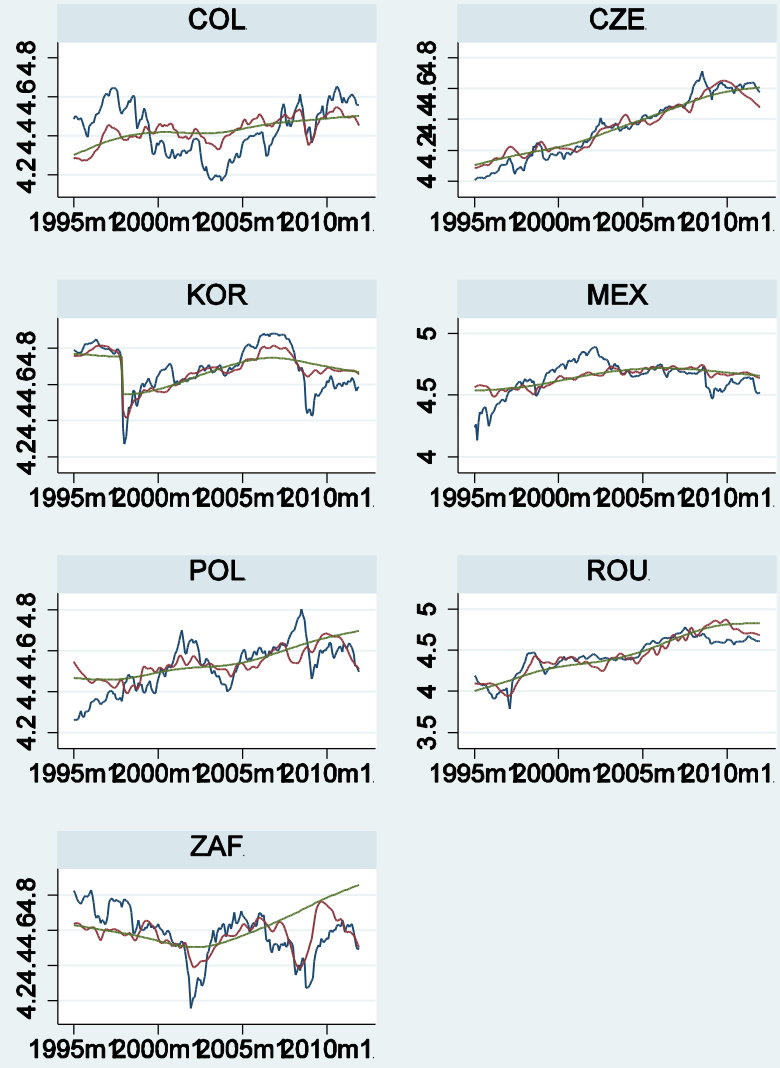

$1995 \mathrm{mR000mR2005mR010m1}$

RER

equilibrium RER (HP filtered fundamentals)

equilibrium RER

Graphs by countries 
Figure 2: Average difference between equilibrium real exchange rate estimates at current versus trend values by regions

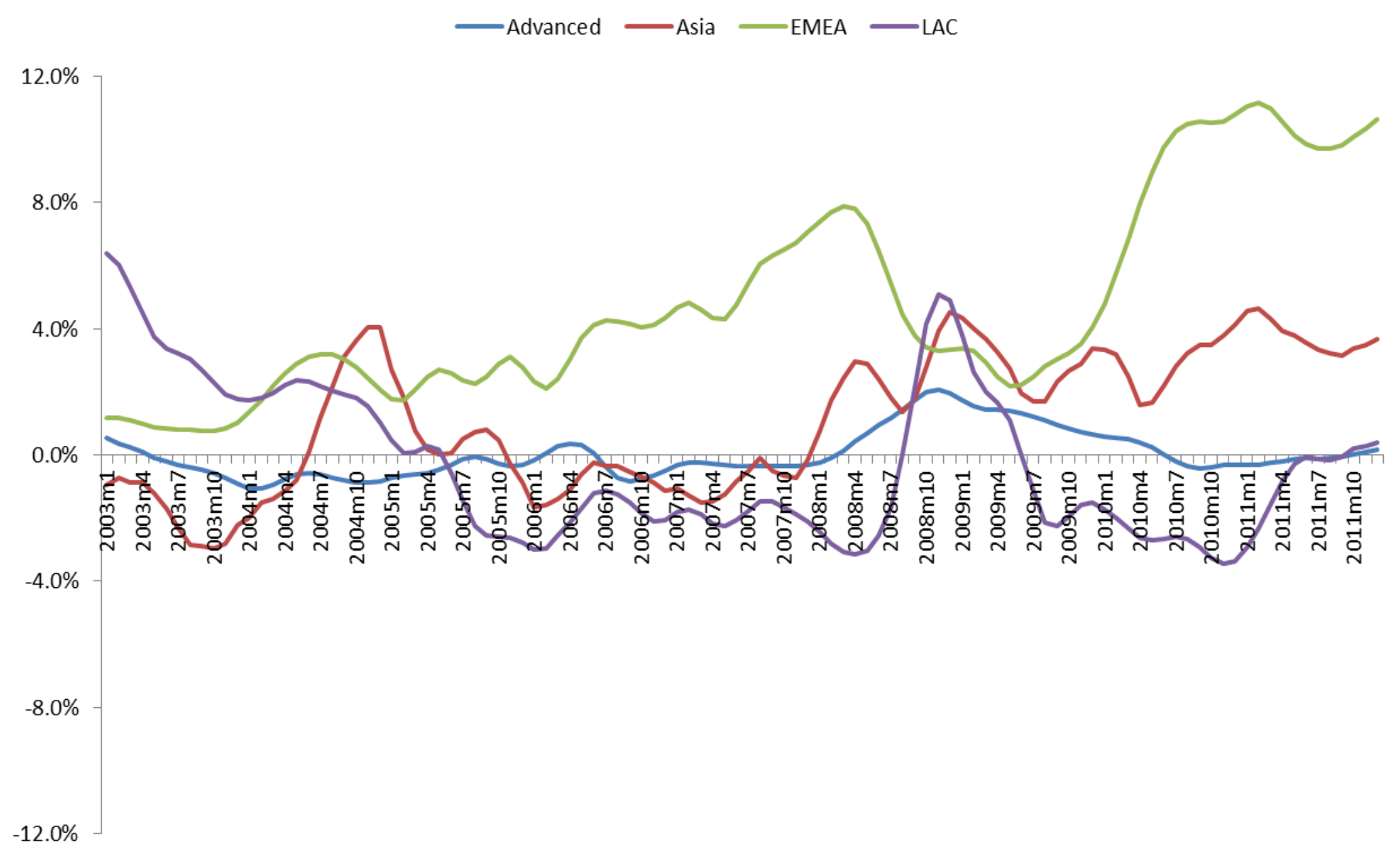


Figure 3: Correlations between intervention effectiveness and financial market characteristics

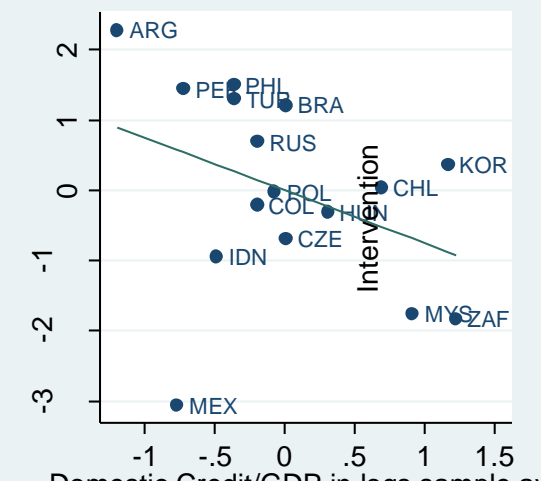

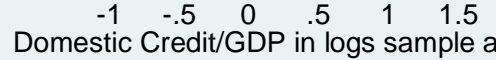
coef $=-.75183486, \mathrm{se}=.50619838, \mathrm{t}=-1.4 \mathrm{\varsigma}$

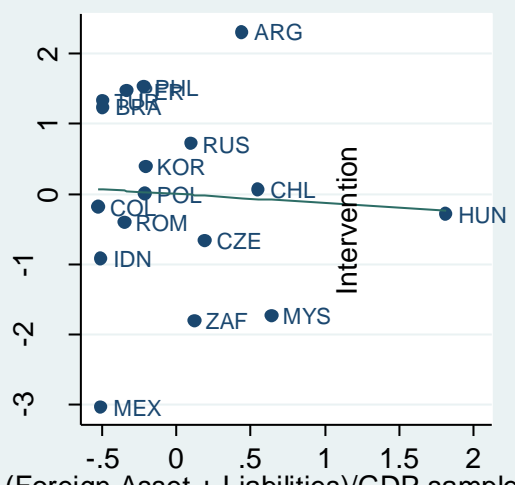

(Foreign Asset + Liabilities)/GDP sample coef $=-.13070909$, se $=.58650642, t=-.22$

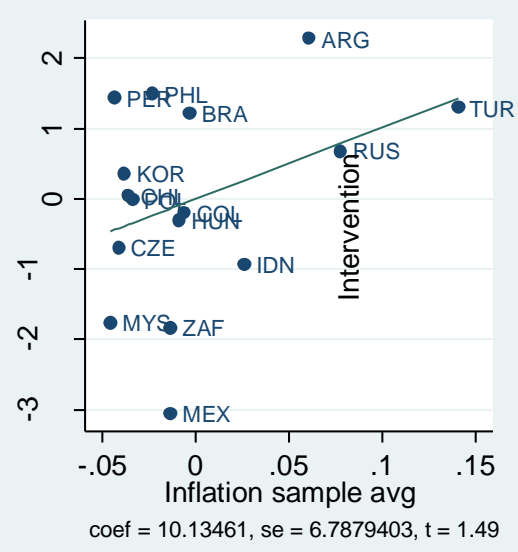

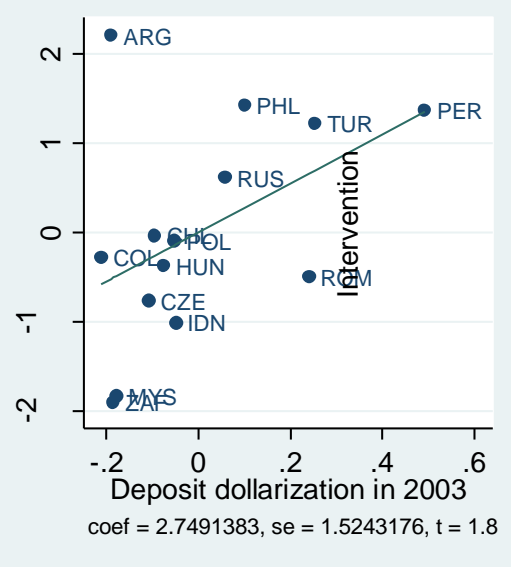

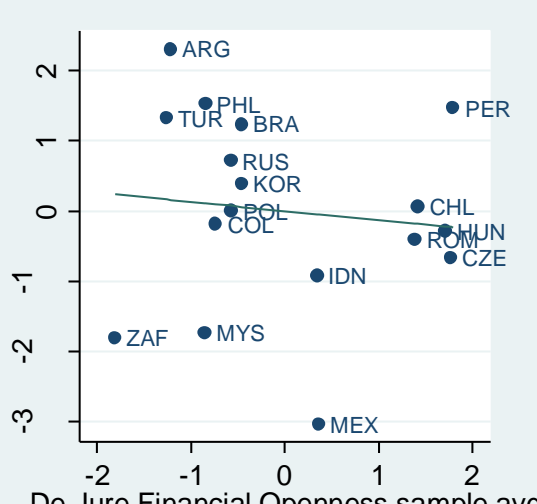

De Jure Financial Openness sample avg coef $=-.12902752, \mathrm{se}=.29719675, \mathrm{t}=-.43$

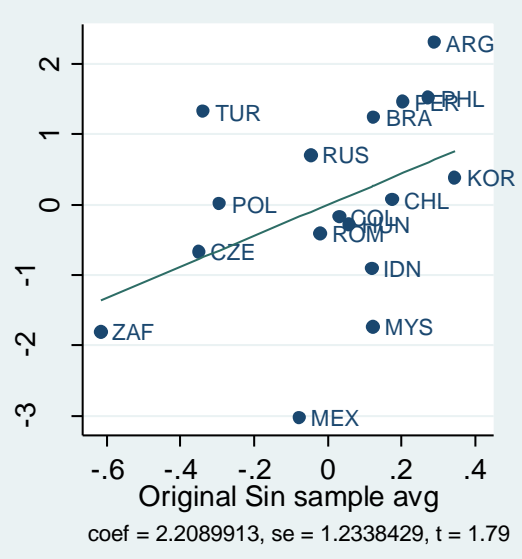




\section{REFERENCES}

ADLER, G. and C. E. TOVAR (2011), "Foreign Exchange Intervention: A Shield Against Appreciation Winds?" IMF Working Paper WP/11/165, International Monetary Fund, Washington DC.

AIZENMAN, J. and J. LEE (2007), "International Reserves: Precautionary Versus Mercantilist Views, Theory and Evidence," Open Economies Review 18(2), pp. 191-214.

BELLO, O., R. HERESI, and R. PINEDA (2010), "El Tipo de Cambio Real de Equilibrio: Un Estudio para 17 países de América Latina," Serie Macroeconomía para el Desarrollo, No. 82, UNECLAC.

BIS (Bank for International Settlements) (2005), "Foreign Exchange Market Intervention in Emerging Markets: Motives, Techniques, and Implications,” BIS Papers, No 24.

BIS (2013), "Market volatility and foreign exchange intervention in EMEs: what has changed?" BIS Papers No. 73.

BRUNO, G.S.F. (2005a), "Approximating the bias of the LSDV estimator for dynamic unbalanced panel data models,” Economics Letters 87, pp. 361-366.

BRUNO, G.S.F. (2005b), "Estimation and inference in dynamic unbalanced panel data models with a small number of individuals," Stata Journal 5(4), pp. 473-500.

CALVO, G.A. and C.M. REINHART (2002), "Fear of Floating," Quarterly Journal of Economics 117(2), pp. 379-408.

CARDENAS, M., K. FODA, C. HENAO and E. LEVY YEYATI (2011), Latin America Economic Perspectives: Shifting Gears in an Age of Heightened Expectations, Brookings, Washington DC.

CHINN, M. D. and H. ITO (2008). “A New Measure of Financial Openness,” Journal of Comparative Policy Analysis 10 (3), pp. 309-322.

DE LA TORRE, A., E. LEVY YEYATI and S. PIENKNAGURA (2013), "Latin America's Deceleration and the Exchange Rate Buffer." LAC Semiannual Report (October), World Bank, Washington, DC.

DISYATAT, P. and G. GALATI (2005), "The effectiveness of foreign exchange intervention in emerging market countries,” BIS Papers No. 24, pp.97-113.

EICHENGREEN, B., R. HAUSMANN and U. PANIZZA (2005), “The Pain of Original Sin,” in Other People's Money, B. Eichengreen and R. Hausmann (eds.), Chicago University Press, Chicago. 
GLÜZMANN, P.A., E. LEVY YEYATI and F. STURZENEGGER (2012), "Exchange rate undervaluation and economic growth: Diaz Alejandro (1965) revisited," Economics Letters 117, pp. 666-672.

HAUSMANN, R., U. PANIZZA and E. STEIN (2001), "Why do countries float the way they float?" Journal of Development Economics 66(2), pp. 387-414.

HAUSMANN, R., L. PRITCHETT and D. RODRIK (2005), "Growth Accelerations," Journal of Economic Growth 10, pp. 303-329.

IMBS, J., H. MUMTAZ, M. RAVN and H. REY (2003), "Non-Linearities and Real Exchange Rate Dynamics," Journal of the European Economic Association 1 (2-3), pp.639-649.

IMF (2006), "Methodology for CGER Exchange Rate Assessments," International Monetary Fund, November, Washington DC.

JOHNSON, S., J.D. OSTRY and A. SUBRAMANIAN (2010), "Prospects for Sustained Growth in Africa: Benchmarking the Constraints," IMF Staff Papers vol. 57(1), pp. 119-171.

JUDSON, R.A. and A.L. OWEN (1999), "Estimating Dynamic Panel Data Models: A Guide for Macroeconomists", Economic Letters, 65(1), pp. 9-15.

KIVIET, J.F. (1995), “On Bias, Inconsistency, and Efficiency of various Estimators in Dynamic Panel Data Models," Journal of Econometrics, 68, pp. 53-78.

KIVIET, J.F. (1999), "Expectation of Expansions for Estimators in a Dynamic Panel Data Model; some Results for Weakly Exogenous Regressors”, in: C. Hsiao, K. Lahiri, L.-F. Lee and M.H. Pesaran (Eds.),,Analysis of Panel Data and Limited Dependent Variables, Cambridge University Press, Cambridge.

KUBOTA, M. (2013), "Estimating the Half-life of Theoretically Founded Real Exchange Rate Misalignments," Policy Research Working Paper 6411, World Bank, Washington DC.

LANE, P. R. and G.M. MILESI-FERRETTI (2007), “The external wealth of nations mark II: Revised and extended estimates of foreign assets and liabilities, 1970-2004”, Journal of International Economics 73, November, 223-250.

LEVY YEYATI, E. (2006), "Financial Dollarization: Evaluating the Consequences", Economic Policy, January 2006, pp. 61-118.

LEVY YEYATI, E. (2010), “What drives reserve accumulation (and at what cost)?” Article published in voxeu.org, September 30. http://www.voxeu.org/article/what-drives-reserve-accumulationand-what-cost 
LEVY YEYATI, E. and F. STURZENEGGER (2010), "Monetary and exchange rate policies," Chapter 64 in Handbook of Development Economics (D. Rodrik and M. Rosenzweig, eds.), Vol. 5, pp. 4215-4281.

LEVY YEYATI, E., F. STURZENEGGER and P.A. GLÜZMANN (2013), "Fear of appreciation," Journal of Development Economics 101, pp. 233-247.

MIHALJEK, D. and M. KLAU (2008), "Exchange rate pass-through in emerging market economies: what has changed and why?” BIS Papers No. 35, pp.103-130.

MOHANTY, M.S. and P. TURNER (2005), “Intervention: what are the domestic consequences?” BIS Papers No. 24, pp. 56-81.

NERLOVE, M. (1971), "Further Evidence on the Estimation of Dynamic Economic Relations from a Time Series of Cross-Sections", Econometrica: Journal of the Econometric Society, pp. 359382.

NICKELL, S. (1981), "Biases in Dynamic Models with Fixed Effects”, Econometrica: Journal of the Econometric Society, pp. 1417-1426.

OBSTFELD, M., J. C. SHAMBAUGH, and A. M. TAYLOR (2010), "Financial Stability, the Trilemma, and International Reserves,” American Economic Journal Macroeconomics 2, pp. 57-94.

RAJAN, R. and A. SUBRAMANIAN (2011), "Aid, Dutch Disease and Manufacturing Growth," Journal of Development Economics 94(1), pp. 106-118.

RODRIK, D. (2008), “The real exchange rate and economic growth: theory and evidence,” Brookings Papers on Economic Activity, Fall 2008. pp. 365-412.

SARNO, L. AND M. P. TAYLOR (2001), “Official Intervention in the Foreign Exchange Market: Is It Effective and, If So, How Does It Work?” Journal of Economic Literature, 39(3), pp. 839-868. 